\title{
An exemplary case of a bromine explosion event linked to cyclone development in the Arctic
}

\author{
A.-M. Blechschmidt ${ }^{1}$, A. Richter ${ }^{1}$, J. P. Burrows ${ }^{1}$, L. Kaleschke ${ }^{2}$, K. Strong ${ }^{3}$, N. Theys ${ }^{4}$, M. Weber ${ }^{1}$, X. Zhao ${ }^{3}$, and \\ A. Zien ${ }^{1, a}$ \\ ${ }^{1}$ Institute of Environmental Physics, University of Bremen, Bremen, Germany \\ ${ }^{2}$ Institute of Oceanography, University of Hamburg, Hamburg, Germany \\ ${ }^{3}$ Department of Physics, University of Toronto, Toronto, Ontario, Canada \\ ${ }^{4}$ Belgian Institute for Space Aeronomy (IASB-BIRA), Brussels, Belgium \\ anow at: Energy \& Meteo Systems GmbH, Oldenburg, Germany \\ Correspondence to: A.-M. Blechschmidt (anne.blechschmidt@iup.physik.uni-bremen.de)
}

Received: 16 July 2015 - Published in Atmos. Chem. Phys. Discuss.: 15 September 2015

Revised: 14 December 2015 - Accepted: 1 February 2016 - Published: 15 February 2016

\begin{abstract}
Intense, cyclone-like shaped plumes of tropospheric bromine monoxide $(\mathrm{BrO})$ are regularly observed by GOME-2 on board the MetOp-A satellite over Arctic sea ice in polar spring. These plumes are often transported by high-latitude cyclones, sometimes over several days despite the short atmospheric lifetime of BrO. However, only few studies have focused on the role of polar weather systems in the development, duration and transport of tropospheric BrO plumes during bromine explosion events. The latter are caused by an autocatalytic chemical chain reaction associated with tropospheric ozone depletion and initiated by the release of bromine from cold brine-covered ice or snow to the atmosphere.

In this manuscript, a case study investigating a commashaped BrO plume which developed over the Beaufort Sea and was observed by GOME-2 for several days is presented. By making combined use of satellite data and numerical models, it is shown that the occurrence of the plume was closely linked to frontal lifting in a polar cyclone and that it most likely resided in the lowest $3 \mathrm{~km}$ of the troposphere. In contrast to previous case studies, we demonstrate that the dry conveyor belt, a potentially bromine-rich stratospheric air stream which can complicate interpretation of satellite retrieved tropospheric $\mathrm{BrO}$, is spatially separated from the observed $\mathrm{BrO}$ plume. It is concluded that weather conditions associated with the polar cyclone favoured the bromine activation cycle and blowing snow production, which may
\end{abstract}

have acted as a bromine source during the bromine explosion event.

\section{Introduction}

Intense plumes of bromine monoxide $(\mathrm{BrO})$ are regularly observed over sea ice during polar spring by satellite (e.g. Richter et al., 1998; Wagner and Platt, 1998; Hollwedel et al., 2003; Choi et al., 2012; Theys et al., 2011; Sihler et al., 2012) and ground-based instruments (e.g. Frieß et al., 2004, 2011; Nghiem et al., 2012). Although subsidence of stratospheric air towards lower altitudes can substantially increase total column BrO (Salawitch et al., 2010), several studies have shown that the plumes are often of tropospheric origin and occur in conjunction with widespread ozone depletion (Barrie et al., 1988; Simpson et al., 2007; Jones et al., 2013). The latter is caused by an autocatalytic, heterogeneous chemical cycle, the so called "bromine explosion" (Barrie and Platt, 1997; Lehrer et al., 1997; Platt and Lehrer, 1997), in which gas phase molecular bromine is photolysed in the presence of sunlight and oxidised subsequently by ozone to form $\mathrm{BrO}$. The latter then reacts with $\mathrm{HO}_{2}$ to form $\mathrm{HOBr}$ which is eventually removed from the atmosphere by wet scavenging. The exact chemical reaction cycle as well as the substrate, from which bromine is initially released to the gas phase are still unclear (Jones et al., 2009). However, there is general agreement that the source must be rich in sea salts and specifically 
in $\mathrm{Br}^{-}$which reacts within the condensed phase substrate to form $\mathrm{Br}_{2}$ which is released to the atmosphere:

$$
\begin{aligned}
& \mathrm{HOBr}+\mathrm{H}^{+}+\mathrm{Cl}^{-} \rightarrow \mathrm{BrCl}+\mathrm{H}_{2} \mathrm{O} \\
& \mathrm{BrCl}+\mathrm{Br}^{-} \rightleftharpoons \mathrm{Br}_{2} \mathrm{Cl}^{-} \\
& \mathrm{Br}_{2} \mathrm{Cl}^{-} \rightleftharpoons \mathrm{Br}_{2}+\mathrm{Cl}^{-} \\
& \mathrm{HOBr}+\mathrm{H}^{+}+\mathrm{Br}^{-} \rightarrow \mathrm{Br}_{2}+\mathrm{H}_{2} \mathrm{O}
\end{aligned}
$$

It is important to note that a $\mathrm{pH}$ lower than 6.5 is required for an efficient bromine activation cycle (Fickert et al., 1999). The possible sequence of reactions involved in the bromine explosion is given in detail in numerous studies (e.g. Sander et al., 2006; Simpson et al., 2007; Buys et al., 2013).

In the past, it was widely believed that frost flowers are a primary source of bromine involved in ozone depletion due to their large surface areas and salinities of about three times higher than in sea water (Rankin et al., 2002). Kaleschke et al. (2004) combined sea ice coverage and tropospheric $\mathrm{BrO}$ from satellite remote sensors with regions potentially covered by frost flowers derived from a simple thermodynamic model. This was based on noting cold surface temperature and related conditions associated with source regions for BrO. They concluded that young ice regions potentially covered by frost flowers are the source of bromine in bromine explosion events (termed BEEs in the following). However, Domine et al. (2005) stated that the role of frost flowers for heterogeneous reactions should be reconsidered, as they measured the total surface area of frost flowers in the Arctic to be only $1.4 \mathrm{~m}^{2} \mathrm{~m}^{-2}$ of ice surface. Roscoe et al. (2011) investigated frost flowers in the lab and could not observe release of aerosols despite wind speeds in gusts up to $12 \mathrm{~m} \mathrm{~s}^{-1}$. Correlating $\mathrm{BrO}$ measurements with air mass histories from meteorological back trajectories, Simpson et al. (2007) identified snow and ice contaminated with sea salt on first-year sea ice as a more likely bromine source compared to frost flowers at Barrow in Alaska. However, results by Obbard et al. (2009) suggest that blowing snow could be salinated by frost flower contact and that, as a consequence, frost flowers and blowing snow in combination are a source of atmospheric bromine.

Yang et al. (2010) found a good agreement with satellitederived tropospheric $\mathrm{BrO}$ when including sublimation of salty blowing snow as a bromine source in a chemical transport model. Pratt et al. (2013) conducted snow chamber experiments on various types of snow and ice surfaces at Barrow, Alaska, and concluded that photochemical production of molecular bromine in surface snow may serve as a major bromine source. They found the most effective production rates of $\mathrm{Br}_{2}$ for tundra snow and the uppermost $1 \mathrm{~cm}$ thick layer of snow on top of first-year sea ice. As the snow chambers were located close to the coast, the inland tundra snow was most likely salinated by atmospheric processes. Using GOME satellite data, Wagner et al. (2001) linked the development of boundary layer $\mathrm{BrO}$ plumes to locations of 1-year old sea ice.
Younger sea ice has gained much attention in studies on BEEs as it is much more salty than older ice (Nghiem et al., 2012) so that snow lying on this ice can easily accumulate sea-salt (Yang et al., 2010). Moreover, liquid brine which forms on fresh ice during the freezing process is highly concentrated in sea-salts. Frost flowers growing on the ice or snow lying on top of it can get coated with the brine through capillary forces (Sander et al., 2006). The likelihood of production of atmospheric $\mathrm{Br}_{2}$ through heterogeneous reaction is enhanced, if the frost flowers, salty snow or sea salt aerosols are lifted up into the air by high wind speeds as will be described below. Nghiem et al. (2012) employed groundbased measurements from the International Polar Year together with satellite observations across sea ice sectors in Alaska and the Canadian Arctic. They showed that stronger BEEs occurred in 2009, when springtime perennial sea ice extent was reduced compared to the previous year. The authors concluded that the strength and frequency of BEEs may increase in the future, as perennial sea ice is replaced by younger, and hence saltier sea ice due to global warming.

Sander et al. (2006) investigated how atmospheric particles produced from alkaline seawater can trigger the acidcatalysed bromine activation cycle using a 1-dimensional atmospheric chemistry model. They concluded that below a temperature of $265 \mathrm{~K}$ most of the carbonate precipitates, which reduces the buffering capacity of sea water and hence facilitates its acidification. Moreover, at low temperatures, the equilibrium constant of Reaction (R2) shifts towards $\mathrm{Br}_{2} \mathrm{Cl}^{-}$which is then transformed to $\mathrm{Br}_{2}$. As ozone depletion events occur at a wide range of low temperatures (Koo et al., 2012), the role of low temperatures for ozone depletion events is still uncertain (e.g., Tarasick and Bottenheim, 2002; Bottenheim et al., 2009; Jacobi, 2010).

Reactive bromine plays a key role in oxidising gaseous elemental mercury to reactive gaseous mercury (Simpson et al., 2007). This increases deposition of mercury to the snow and ice which is harmful to the environment (Steffen et al., 2008). BEEs therefore not only cause ozone depletion events, but also atmospheric mercury depletion events during polar spring.

Satellite images show that many $\mathrm{BrO}$ plumes observed over polar sea-ice regions are spiral or comma-shaped and resemble high-latitude cyclones in appearance. However, not much is known on the role these weather systems play for the formation, duration and transport of BEEs. In the past, it was widely believed that all BEEs form within a stable boundary layer and are accompanied by low near-surface wind speeds. Subsequent transport of the bromine plumes from their genesis regions explained why large concentrations of bromine were also observed at high wind speeds (e.g. Barrie et al., 1988; Frieß et al., 2004). In contrast to this, Jones et al. (2009) showed that a stable boundary layer acting as a "closed reaction chamber" (Simpson et al., 2007) is not a prerequisite for the development of BEEs. Jones et al. (2009) developed a qualitative model showing that the likelihood of 
ozone depletion is strongly enhanced at very calm weather conditions and at wind speeds larger than $10 \mathrm{~m} \mathrm{~s}^{-1}$. They argued that both weather situations increase the number of reactants in the air and facilitate contact between the gaseous and condensed phase, thereby favouring bromine explosions. Their findings were supported by observations of an Antarctic BEE, for which high wind speeds caused by a cyclone and saline blowing snow were reported. Jones et al. (2010) investigated the vertical structure of ozone depletion events based on ozone measurements from two Antarctic field campaigns and found that those events which occurred at wind speeds below $7 \mathrm{~m} \mathrm{~s}^{-1}$ did not exceed $40 \mathrm{~m}$ in the vertical, while those observed at altitudes above $1 \mathrm{~km}$ were accompanied by high wind speeds caused by low pressure systems. They concluded that high wind speeds and rising motions within cyclones cause uptake of snow to the air, which in turn caused the observed bromine explosions. Begoin et al. (2010) conducted a case study of a $\mathrm{BrO}$ plume in the Arctic, which was seen on GOME-2 satellite images for at least 5 days and was transported by a cyclone over a large distance. They concluded that recycling of $\mathrm{BrO}$ on wind blown snow or aerosol surfaces enhanced the lifetime of the plume substantially.

The present study aims to improve knowledge of the role of high-latitude cyclones in BEEs. We present GOME-2 satellite observations of a tropospheric $\mathrm{BrO}$ plume which developed in late March 2011 over the Beaufort Sea to the north of Alaska. As will be shown below, the evolution of this BEE is closely linked to weather conditions and transport within a polar cyclone and it is therefore termed "bromine cyclone transport event" or BCTE in the following. Here, GOME-2 retrievals of tropospheric $\mathrm{BrO}$ are regarded as an indicator of activated bromine species (such as $\mathrm{Br}, \mathrm{Br}_{2}, \mathrm{HOBr}$ and $\mathrm{BrCl}$ ) in general, although activated bromine species may also be present in the absence of $\mathrm{BrO}$. The regional Weather Research and Forecasting (WRF) (Skamarock et al., 2008) model is used to investigate meteorological conditions during the BCTE. As only columns of tropospheric BrO, i.e. no information on vertical distribution, are available from GOME2, runs with the Lagrangian FLEXible PARTicle dispersion model (FLEXPART) (Stohl et al., 2005) are carried out to derive information on the altitude of the $\mathrm{BrO}$ plume. Moreover, conclusions on the location of the plume in relation to airflows within the polar cyclone and on possible $\mathrm{BrO}$ sources are derived from additional satellite data. In contrast to previous studies on BCTEs using satellite data, we show that the dry conveyor belt as a potentially bromine-rich stratospheric airstream is spatially separated from the $\mathrm{BrO}$ plume for the case investigated.

Satellite data used in the present study will be described in Sect. 2. Details on WRF and FLEXPART model set-ups are given in Sect. 3, followed by results in Sect. 4. The paper ends with a summary and conclusions (Sect. 5).

\section{Satellite data}

\subsection{GOME-2}

GOME-2 (Global Ozone Monitoring Experiment-2; Callies et al., 2000) is a UV-vis nadir-viewing spectrometer on board MetOp-A (Meteorological Operational SatelliteA) and MetOp-B. It measures the upwelling radiance backscattered from Earth and the extraterrestrial solar irradiance between 240 and $790 \mathrm{~nm}$ with a footprint size of $40 \mathrm{~km} \times 80 \mathrm{~km}$. GOME-2 is in a sun-synchronous polar orbit with an equator-crossing time of 09:30 LT in descending node.

The method for deriving tropospheric $\mathrm{BrO}$ used here is similar to the one used by Begoin et al. (2010), which accounts for stratospheric $\mathrm{BrO}$ amounts based on the method of Theys et al. (2011). First, BrO total slant column densities are retrieved from GOME-2 (MetOp-A) data by application of the Differential Optical Absorption Spectroscopy (DOAS) (Platt, 1994) method to a 336-347 nm fitting window (Afe et al., 2004). The fit includes absorption cross-sections of $\mathrm{O}_{3}$ (223 and $\left.273 \mathrm{~K}\right)$ (Gorshelev et al., 2014; Serdyuchenko et al., 2014), $\mathrm{NO}_{2}$ (223 K) (Burrows et al., 1998) and $\mathrm{BrO}$ (Fleischmann et al., 2004) as well as a Ring-pseudo-spectrum for correction of the effect of Rotational Raman scattering (Vountas, 1998) and a polynomial of order 4. Second, stratospheric vertical column densities (VCDs) of $\mathrm{BrO}$ are estimated using the Theys et al. (2011) climatology of stratospheric BrO from the BASCOE (Errera et al., 2008; Viscardy et al., 2010) chemical transport model and dynamical tropopause heights (defined in this study as the height of the 3 PVU potential vorticity surface) derived from WRF output (see Sect. 3.1 for details on the model set-up). Stratospheric VCDs are then converted to slant column densities by application of a stratospheric air mass factor. In the last step, VCDs of tropospheric $\mathrm{BrO}$ are calculated by subtracting stratospheric from total slant column densities and dividing the result by a tropospheric air mass factor. For derivation of the tropospheric air mass factor, we assume that all $\mathrm{BrO}$ is located and well mixed within the lowermost $400 \mathrm{~m}$ of the troposphere over ice or snow with a surface spectral reflectance for the viewing angle of 0.9 . Hence, $\mathrm{BrO}$ amounts are underestimated outside ice and snow covered regions, which means away from areas where the BCTE was observed. In this paper, GOME-2 results are shown for solar zenith angles smaller than $80^{\circ}$ only.

No cloud flagging technique is applied to GOME-2 retrievals shown in the following sections. The reason for this is twofold. On the one hand, it is very difficult to differentiate clouds from sea ice or snow covered surfaces using passive remote sensors. On the other hand, applying a cloud flag to the data would most likely eliminate fronts from tropospheric $\mathrm{BrO}$ observations. Fronts indicate vertical lifting and are therefore of particular interest when looking at BCTEs. Hence, $\mathrm{BrO}$ amounts may be underestimated, if $\mathrm{BrO}$ is lo- 


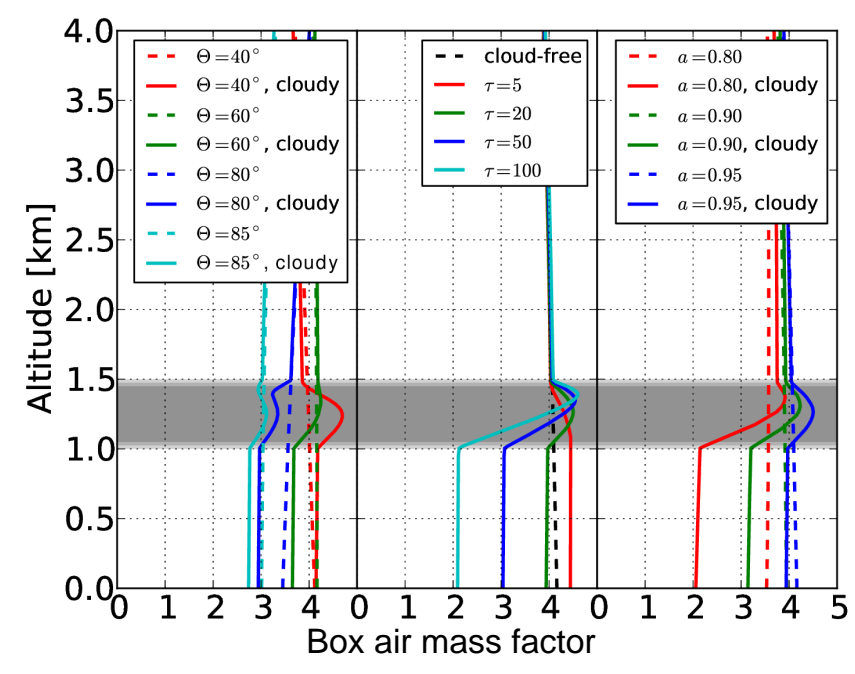

Figure 1. Radiative transfer simulations showing sensitivity of satellite observations to $\mathrm{BrO}$ in the boundary layer under (dashed lines) cloud-free and (solid lines) cloudy conditions. The panels show the influence of (left) solar zenith angle $\theta$, (middle) cloud optical thickness $\tau$ and (right) surface albedo $a$ on the box air mass factor. All simulations are at a wavelength of $350 \mathrm{~nm}, \theta=50^{\circ}, \tau=20$, and $a=0.9$ unless noted otherwise.

cated below optically thick clouds, and $\mathrm{BrO}$ sensitivity can be enhanced, if $\mathrm{BrO}$ is located within or above a cloud (e.g., Begoin et al., 2010; Sihler et al., 2012). However, the former (shielding) effect is much less pronounced over bright surfaces (e.g., Begoin et al., 2010; Vasilkov et al., 2010), i.e. over areas where the BCTE was observed. This is demonstrated by Fig. 1 showing SCIATRAN (Rozanov et al., 2005) radiative transfer simulations of the sensitivity of satellite observations to $\mathrm{BrO}$ in the boundary layer under different cloud conditions, solar zenith angles and surface albedos. The SCIATRAN runs were performed for clouds at 1 to $1.5 \mathrm{~km}$ altitude, which is broadly representative of GOME-2 results shown in this paper (see Sect. 4). The sensitivity is expressed in the form of an altitude-dependent air mass factor, the so called box air mass factor. Over bright surfaces, even clouds with optical thicknesses of 20 or more do not completely block $\mathrm{BrO}$ close to the ground from the satellite view. The latter is explained by the effect of multiple scattering between surface and cloud bottom which enhances the light path below the cloud, partly compensating for the smaller number of photons which penetrate the cloud. The influence of clouds on box air mass factors does not vary much for solar zenith angles between 60 and $80^{\circ}$, which is characteristic for the BCTE observations discussed in this paper.

Further investigation of GOME-2 $\mathrm{O}_{4}$ retrievals (not shown) indicate that light path enhancement due to multiple scattering caused by clouds cannot explain the large VCDs observed inside the $\mathrm{BrO}$ plume for the case investigated in the present study. This agrees with the box air mass factor displayed in Fig. 1, which only shows a rather small increase in the upper parts of clouds compared to the cloud-free case, even for a cloud optical thickness of 100 .

GOME-2 total columns of ozone derived using the Weighting Function DOAS (WFDOAS) (Coldewey-Egbers et al., 2005; Weber et al., 2005; Bracher et al., 2005) are incorporated in the present study to better differentiate between stratospheric and tropospheric air flows within the polar cyclone.

\subsection{MODIS}

The Moderate Resolution Imaging Spectroradiometer (MODIS) on board the National Aeronautics and Space Administration (NASA) Terra and Aqua satellites measures visible and thermal electromagnetic radiation in 36 spectral bands between 0.4 and $14.4 \mu \mathrm{m}$ (http://modis.gsfc.nasa.gov). In this manuscript, false colour images are constructed using the $2.1 \mu \mathrm{m}$ mid-infrared channel for both red and green and the $0.85 \mu \mathrm{m}$ visible channel as blue following the blowing snow detection method by Palm et al. (2011). For such imaging, snow and ice on the ground should appear blue, as their signal stands out in the visible, while clouds and suspended snow particles should appear yellow, as these cause signals which stand out in the mid-infrared (Palm et al., 2011). MODIS false colour images are used here to investigate if blowing snow may have contributed as a bromine source during the BCTE and, in combination with GOME-2 ozone observations, to distinguish between stratospheric and tropospheric air flows. The MODIS data with $1 \mathrm{~km}$ horizontal resolution are provided by NASA through the MODIS website (http://modis.gsfc.nasa.gov).

\subsection{SMOS}

The Microwave Imaging Radiometer with Aperture Synthesis (MIRAS) on board the Soil Moisture and Ocean Salinity (SMOS) satellite measures radiance emitted by the Earth at L-Band $(1.4 \mathrm{GHz})$. MIRAS has a footprint of $35 \mathrm{~km}$ in nadir, while the footprint is $45 \mathrm{~km}$ at the edges of the swath (Kaleschke et al., 2012). An iterative retrieval algorithm was used to calculate sea ice thickness from the $1.4 \mathrm{GHz}$ near nadir brightness temperature (Tian-Kunze et al., 2014). SMOS sea ice thickness maps are indicative of conditions for sea ice surfaces with high salinity because the $1.4 \mathrm{GHz}$ brightness temperature is in particular sensitive to thin ice and leads in sea ice.

\subsection{CALIOP}

The Cloud Aerosol Lidar with Orthogonal Polarization (CALIOP) on board the Cloud-Aerosol Lidar Infrared Pathfinder Satellite Observation (CALIPSO) satellite is a two-wavelength polarisation-sensitive lidar which provides high-resolution vertical profiles of clouds and aerosols (http: //www-calipso.larc.nasa.gov). As it is difficult to obtain cloud information from passive remote sensors over snow or 


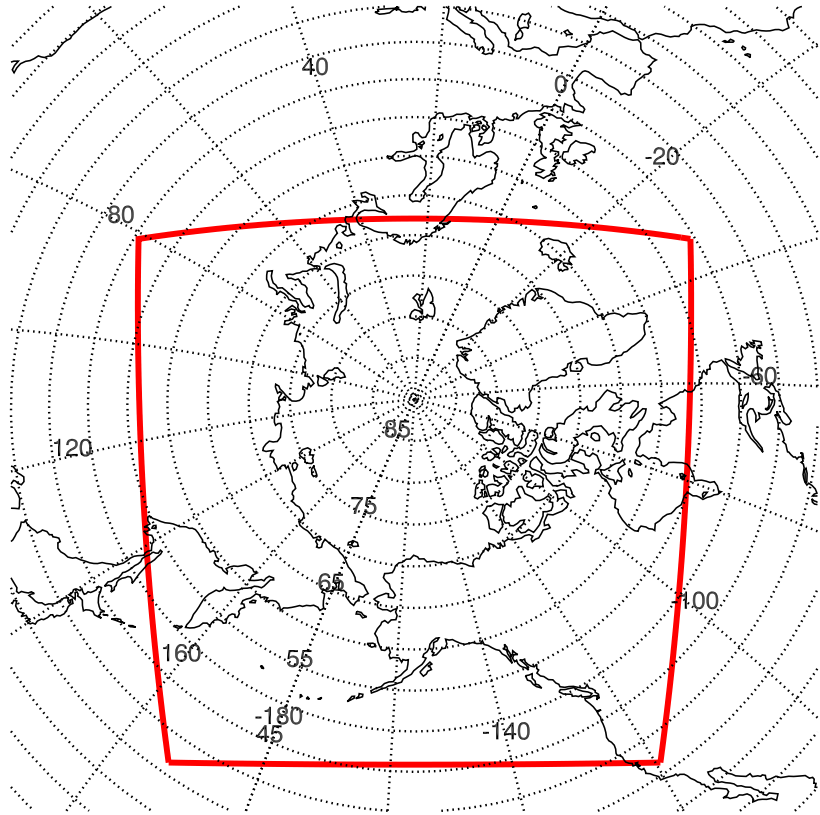

Figure 2. The WRF model domain (red box).

sea ice, CALIOP is used to investigate cloud top altitudes inside the BCTE. CALIOP data were obtained from the NASA Langley Research Center Atmospheric Science Data Center through their website at http://eosweb.larc.nasa.gov/.

\section{Numerical model simulations}

\subsection{WRF}

The WRF model is a mesoscale numerical weather prediction and atmospheric simulation system developed at the National Center for Atmospheric Research (NCAR) (Skamarock et al., 2008).

Here, we use WRF version 3.6 to simulate meteorological conditions for a $7600 \mathrm{~km} \times 7600 \mathrm{~km}$ sized domain centred on the development region of the BCTE (see Fig. 2 for the borders of the model domain). The model is run with a horizontal grid spacing of $20 \mathrm{~km} \times 20 \mathrm{~km}, 30$ levels in the vertical and a model top at $50 \mathrm{hPa}$. NCEP Final Analysis (FNL from GFS) 6-hourly data with $1^{\circ}$ resolution are used to initialise meteorological conditions and as boundary conditions. The NCEP FNL data were provided by the Computational and Information Systems Laboratory (CISL) Research Data Archive through their web site at http://dss.ucar.edu/. The simulation starts on 31 March 2011 at 00:00 UTC and ends on 3 April at 00:00 UTC. WRF output is produced at a half-hourly time step, so that the model output is close to satellite observation times.

Our model set-up includes the Mellor-Yamada-Janjic planetary boundary layer scheme (Janjic, 1994), Lin et al. (1983) for cloud microphysics, the Dudhia (1989) shortwave radia- tion scheme and the Rapid Radiative Transfer Model longwave radiation scheme (Mlawer et al., 1983).

\subsection{FLEXPART}

FLEXPART is a Lagrangian trajectory model suitable for simulating a large range of atmospheric transport processes (http://www.flexpart.eu). It has been used in atmospheric chemistry research to examine source regions for aircraft, satellite, ground-based station, and ship-based studies (Stohl et al., 2005; Stohl, 2006; Warneke et al., 2009; Begoin et al., 2010; Gilman et al., 2010; Hirdman et al., 2010).

In the present study, FLEXPART is run forward in time for a passive $\mathrm{BrO}$ tracer which is transported by winds from $1^{\circ}$ resolution NCEP Final Analysis 6-hourly data. As knowledge of $\mathrm{BrO}$ chemistry is limited, simulations are kept as simple as possible, so that the $\mathrm{BrO}$ tracer is not removed by wet or dry deposition and no assumptions on its lifetime were made. Convection is accounted for in our model configuration. FLEXPART output is produced half-hourly (as for WRF, see Sect. 3.1) on a $1^{\circ}$ resolution grid.

FLEXPART runs are initialised by daily averaged GOME2 satellite retrievals of tropospheric $\mathrm{BrO}$ following the method of Begoin et al. (2010). To identify the most likely source regions of tropospheric $\mathrm{BrO}$ for this event, which we expect to be located in close proximity of the plume, only satellite data with values above $5 \times 10^{13}$ molec $\mathrm{cm}^{-2}$ and between 140 and $280^{\circ} \mathrm{E}$, to the north of $65^{\circ} \mathrm{N}$ are regarded here.

Results from three different sets of simulations will be shown below. The first set of FLEXPART simulations (FS1) is started and initialised on 1 April at 00:00 UTC by daily averaged satellite observations from approximately 31 March at 22:00 UTC to 1 April at 01:00 UTC. Note that possible initialisation times are limited to the 6-hourly time resolution of NCEP Final Analysis data. As the BrO plume location is nearly stationary for all orbits included in this satellite mean, we expect possible effects resulting from time gaps between initialisation and satellite observation to be negligible. The second set of simulations (FS2) is started and initialised on 2 April at 00:00 UTC by satellite observations from 1 April at about 20:00-23:00 UTC. Again, the plume is to a good approximation stationary for all orbits included in the satellite mean for 1 April. The third set of simulations (FS3) use the same set up as FS2, but in addition to the latitude and longitude boundaries given above, only observations up to $76^{\circ} \mathrm{N}$ are regarded here.

Each set of FLEXPART experiments consists of six model runs assuming that the plume was located between $0-1,1-3$, $3-5,5-7,7-9$ or $9-11 \mathrm{~km}$ at time of initialisation. This means that the higher elevation runs are initialised by plumes above the tropopause. As will be described in the following section, the FLEXPART runs show that the plume resided in the troposphere, confirming that GOME-2 observed a tropospheric feature. 


\section{Results}

In this section, results on links between the polar cyclone and the associated bromine explosion will be presented. In principal there are three conceivable explanations for the occurrence of polar tropospheric $\mathrm{BrO}$ plumes in GOME-2 satellite images: (1) the plume is a result of light path enhancement within clouds possibly combined with shielding of $\mathrm{BrO}$ below optically thick clouds at other locations, (2) the plume is due to subsidence of stratospheric, bromine rich air towards lower altitudes, which strongly enhances total column $\mathrm{BrO}$ and the stratospheric correction method failed to remove this air mass from tropospheric $\mathrm{BrO}$ VCDs, (3) the plume developed due to the bromine explosion chemical reaction in the boundary layer with possible subsequent transport towards higher altitudes in the troposphere. In Sect. 2.1, it was shown that the first explanation is not valid for the BCTE investigated in this paper. We will show in the following that the second point is also not valid, whereas plume development due to the bromine explosion mechanism in the boundary layer can reasonably explain the occurrence of the observed tropospheric $\mathrm{BrO}$ plume.

Figure 3 shows satellite observations, together with parameters used for GOME-2 tropospheric $\mathrm{BrO}$ retrieval, covering different development stages of the BCTE. The first GOME-2 observation of the tropospheric $\mathrm{BrO}$ plume was made on 31 March at approximately 22:00 UTC (not shown). At this time, the plume was already shaped like a comma, resembling the clouds of a polar cyclone in appearance. As the bromine explosion chemical reaction cycle requires daylight, the BCTE most likely developed between sunrise (approximately at 15:40 UTC) and 22:00 UTC on 31 March. It was generated to the north of Alaska over the Beaufort Sea, which was covered by sea-ice at this time of the year. The location as well as spatial pattern of the plume did not change from the first to the second GOME-2 observation (see next paragraph). Moreover, similar meteorological conditions were present at plume location for both satellite observations.

At 23:30 UTC on 31 March (Fig. 3a, left panel), absolute values of tropospheric BrO VCDs had increased by about $4 \times 10^{13}$ molec $\mathrm{cm}^{-2}$ inside the plume. This may indicate that the BCTE had intensified, but may also result from differing satellite viewing conditions. Figure 4 shows meteorological conditions from the WRF simulation corresponding to GOME-2 observation times shown in Fig. 3. Comparison of both figures shows that the plume was located to the west of a low pressure system at an occluded front (shown by $2 \mathrm{~m}$ temperature patterns in Fig. 4c, left panel), which means that northerly wind directions prevailed during the development of the event. Wind speeds reached about $10 \mathrm{~m} \mathrm{~s}^{-1}$ at the plume location. Note that fronts indicate vertical lifting. This is in agreement with the, relative to the surrounding areas, high planetary boundary layer height (Fig. 4e) values at plume and front location. The latter is true for all development stages of the $\mathrm{BrO}$ plume.
On 1 April at 21:30 (Fig. 3a, middle panel), the $\mathrm{BrO}$ plume had fully developed. WRF simulations indicate that the plume was transported cyclonically eastwards around the low pressure system, which had also deepened at this time of development, reaching minimum mean sea level pressure values of approximately $983 \mathrm{hPa}$ (see Fig. 4a, middle panel). South-westerly winds of up to $15 \mathrm{~m} \mathrm{~s}^{-1}$ prevailed at the plume location. The wind speed maximum was located around $160^{\circ} \mathrm{W}, 76^{\circ} \mathrm{N}$ which coincides with convergent wind directions, indicating strong north-eastwards directed uplift at the southern end of the $\mathrm{BrO}$ plume, which is in agreement with the planetary boundary layer height pattern shown in Fig. $4 \mathrm{e}$.

On 2 April at 19:30 UTC (Fig. 3a, right panel), the plume had moved further north-eastwards with the low pressure system and reached the Canadian High Arctic Archipelago. Values inside the plume had decreased and the plume had lost its comma-shape indicating the dissolving stage of the BCTE. Likewise, the low pressure system weakened and the cyclone lost frontal structure (see Fig. 4, right panels). However, wind speeds were still quite high (up to about $13 \mathrm{~m} \mathrm{~s}^{-1}$ ) and blowing from southerly directions at plume location.

On 3 April (not shown), parts of the diluted plume were observed at the Polar Environment Atmospheric Research Laboratory (PEARL) on Ellesmere Island by ground-based Multi Axis-DOAS. The BCTE arrived at PEARL late on 3 April. Investigation of NCEP/NCAR Reanalysis (Kalnay et al., 2013) data (not shown) reveals that by 5 April, the weather system associated with the BCTE had joined another, more southerly low-pressure system. This resulted in low wind speed weather conditions different from those discussed in this study. The measurements at PEARL, documenting the arrival of the plume during blowing snow weather conditions followed by local recycling of $\mathrm{BrO}$ under stable shallow boundary layer conditions, are described in detail by Zhao et al. (2016). Overall, the observed lifetime of the high wind speed BCTE is about 4 days according to GOME-2 observations, covering the onset (evening of 31 March), mature stage (evening of 1 April) and dissolving stage (evening of 2 April).

The location of the BrO plume observed by GOME-2 broadly coincides with regions of low temperatures around 350 geopotential metres (gpm) (see Fig. 4d, the difference between geopotential heights and altitudes above ground is assumed to be negligible) simulated by WRF, although the relation is less clear during the development of the event compared to later stages. The $\mathrm{BrO}$ plume location also broadly coincides with regions of low temperatures at higher altitudes up to roughly $500 \mathrm{gpm}$ during the development stage and roughly $1000 \mathrm{gpm}$ for the mature and dissolving stage of the BCTE. This is in agreement with the results by Sander et al. (2006) (see Sect. 1), who found that recycling of $\mathrm{BrO}$ on aerosol surfaces is most efficient at low temperatures.

Figure 5 shows sea ice thickness retrieved by SMOS for 1 April. This date is chosen as a proxy of sea ice thick- 
(a)

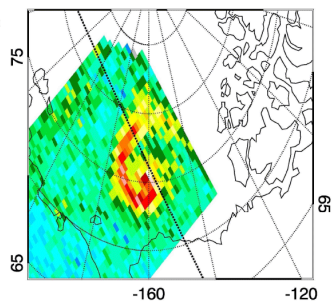

(b)

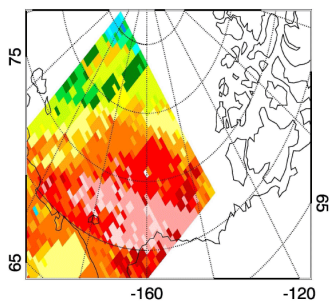

(c)

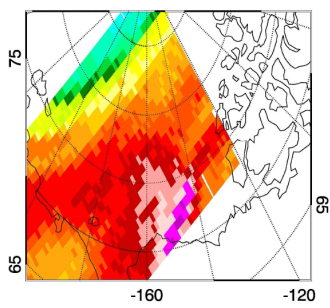

(d)

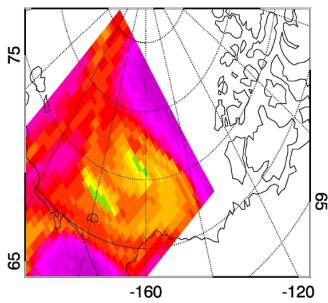

(e)

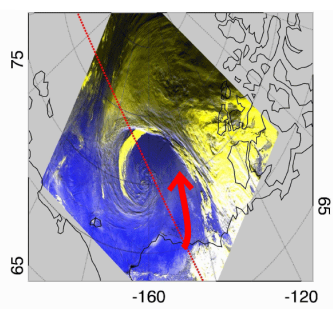

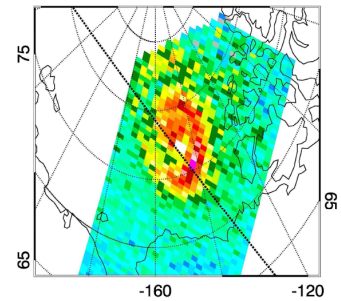
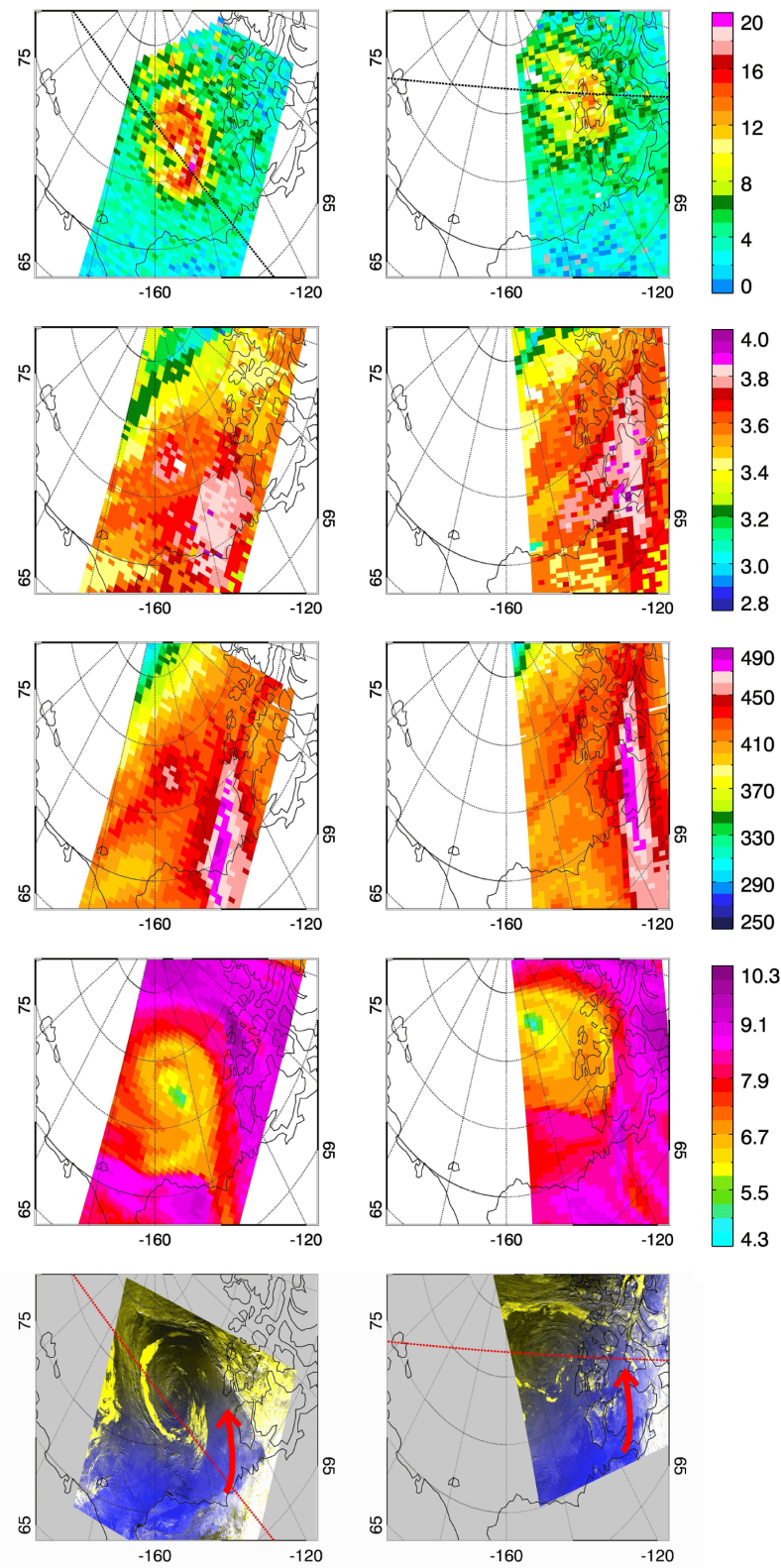

Figure 3. Satellite observations, together with parameters used for GOME-2 tropospheric BrO retrieval, of the BCTE showing (a) GOME$2 \mathrm{BrO}$ tropospheric VCD $\left[10^{13}\right.$ molec $\left.\mathrm{cm}^{-2}\right]$, (b) GOME-2 BrO stratospheric VCD $\left[10^{13}\right.$ molec $\left.\mathrm{cm}^{-2}\right]$, (c) GOME-2 ozone VCD [DU], (d) WRF tropopause height $[\mathrm{km}]$ and (e) MODIS false colour images. Shown from left to right are different development stages of the BCTE: onset (31 March 2011 at 23:30 UTC for GOME-2 and WRF, 23:15 UTC for MODIS), mature stage (1 April 2011 at 21:30 UTC for GOME-2 and WRF, 22:20 UTC for MODIS) and dissolving stage (2 April 2011 at 19:30 UTC for GOME-2 and WRF, 19:45 UTC for MODIS). Red arrows plotted on top of MODIS false colour images indicate the location of the dry conveyor belt (see Sect. 4 for further details). The red dotted lines in MODIS false colour images and black dotted lines in GOME-2 BrO tropospheric VCD images correspond to CALIPSO tracks for the CALIOP observations shown in Fig. 7.

ness conditions for other days during the BCTE (potential bromine sources deduced from SMOS images do not change significantly from late March to early April 2011). SMOS shows reduced sea ice thicknesses in the area around $170^{\circ} \mathrm{W}$, $77.5^{\circ} \mathrm{N}$ and $158^{\circ} \mathrm{W}, 74^{\circ} \mathrm{N}$ (these regions are indicated by black arrows in Fig. 5). Comparing GOME-2 observations of the BrO plume to SMOS retrievals and considering wind directions simulated by WRF, we infer that the former identified region may have acted as a bromine emission source during the onset of the BCTE, while the latter region may have been a source of bromine during the mature stage of the event. 
(a)

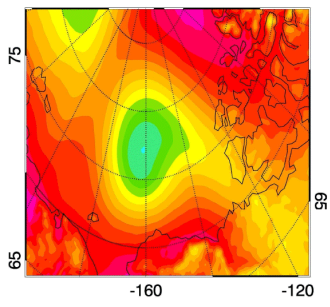

(b)

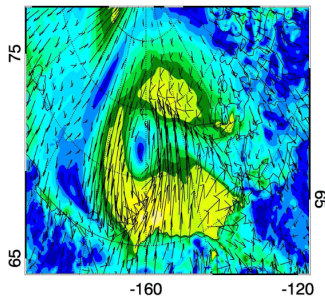

(c)

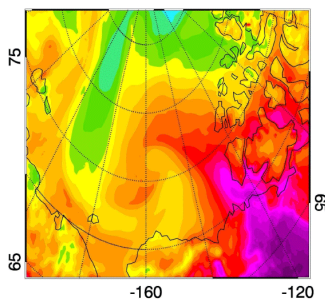

(d)

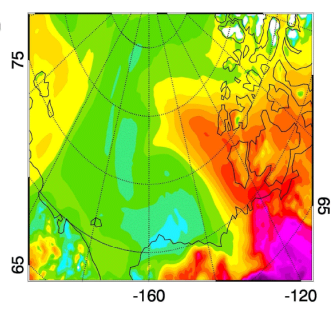

(e)

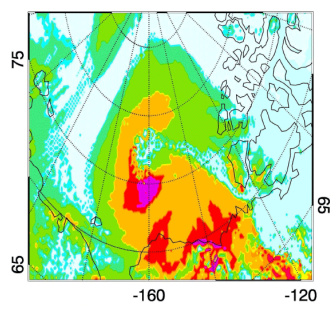

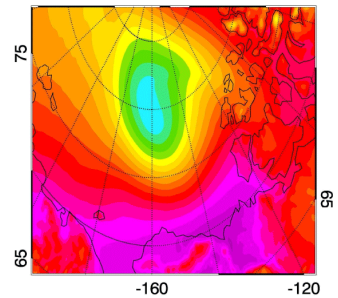
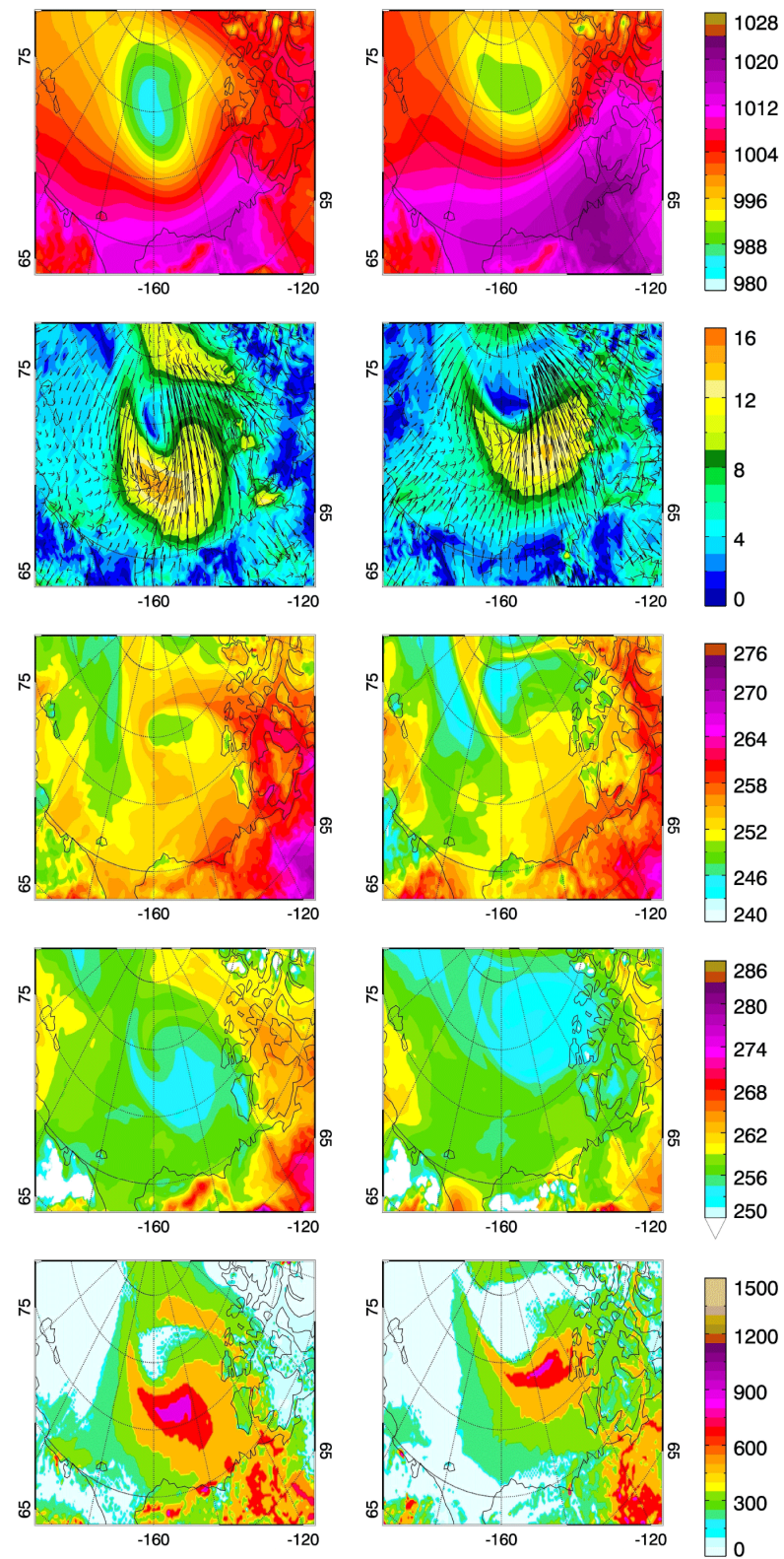

Figure 4. WRF weather simulations of the BCTE for (a) sea level pressure [hPa], (b) wind direction (black arrows) and wind speed [ $\mathrm{m} \mathrm{s}^{-1}$ ] (coloured shadings), (c) temperature [K] at $2 \mathrm{~m}$ above ground, (d) temperature $[\mathrm{K}]$ at $350 \mathrm{gpm}$ (note that the colour bar differs for $\mathbf{c}$ and $\mathbf{d}$ ) and (e) planetary boundary layer height [m]. Shown from left to right are simulations for different development stages of the BCTE: onset (31 March 2011 at 23:30 UTC), mature stage (1 April 2011 at 21:30 UTC) and dissolving stage (2 April 2011 at 19:30 UTC).

To identify the location of the $\mathrm{BrO}$ plume with respect to cyclonic air flows, ozone VCDs [DU] from GOME-2 as well as MODIS false colour images close to GOME-2 observation times are shown in Fig. $3 c$ and e, respectively. Note that further inspection of all MODIS observations of the BCTE available before and after each GOME-2 observation indicates that MODIS orbits shown in Fig. 3 are to a good approximation representative of cloud and/or blowing snow conditions at GOME- 2 observation times. The dry conveyor belt is a low moisture, ozone-rich air stream within an extra-tropical cyclone, descending from the lower stratosphere towards tropospheric altitudes. On satellite images, a dry intrusion can be identified as a nearly cloud-free region sandwiched between a high-topped cloud band associated with the cold front and an often lower cloud head (Browning, 1997). The location of this air stream, coinciding with high ozone VCDs observed by GOME-2, is indicated by red arrows plotted on top of MODIS false colour images in Fig. 3e. Apart from enhanced ozone VCDs near the cloud head, where the dry conveyor belt most likely overlaps with 


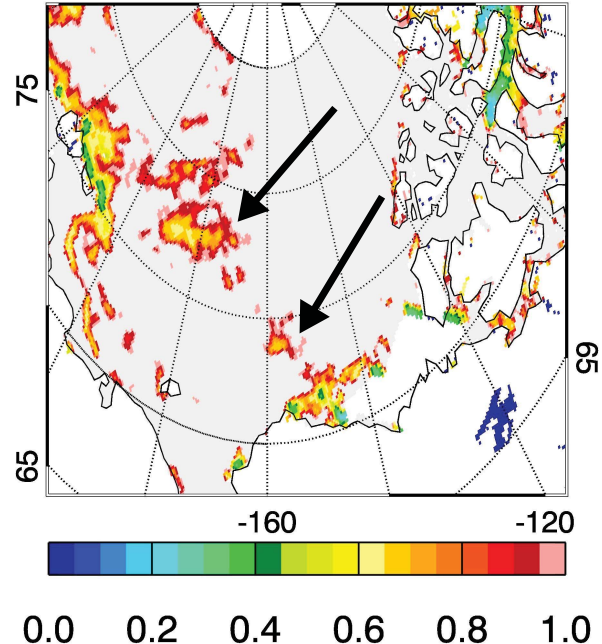

Figure 5. SMOS satellite retrievals of sea ice thickness [m] for 1 April 2011. Values larger than $1 \mathrm{~m}$ are generally related to large uncertainties and are therefore shown in light grey colour. Potential bromine source regions (see Sect. 4) are indicated by black arrows.

tropospheric air flows, the dry conveyor belt is clearly separated from the $\mathrm{BrO}$ plume. Moreover, the plume pattern is not significantly correlated with low WRF tropopause heights shown in Fig. 3d. In this sense, this BEE differs from previous case studies for which the dry conveyor belt complicated the interpretation of tropospheric $\mathrm{BrO}$ or total column $\mathrm{BrO}$ from satellite retrievals (e.g., Begoin et al., 2010; Salawitch et al., 2010), so that the contribution of stratospheric air to the observed $\mathrm{BrO}$ plumes remained uncertain. Note that the high ozone values coincide with high GOME-2 stratospheric $\mathrm{BrO}$ VCDs (Fig. 3b), which is in agreement with conclusions drawn in this paragraph.

The MODIS images shown in Fig. 3 reveal that the $\mathrm{BrO}$ plume moved with the occluded front and generally coincided with cloudy areas. As clouds indicate vertical mixing, it is likely that the plume development is closely linked to regions of vertical uplift and high wind speeds near the cyclone centre. In agreement with the study by Jones et al. (2009), these weather conditions are favourable for blowing brine wetted snow production, which may have acted as a bromine source during the BCTE. This conclusion is strengthened by mesoscale features shown in Fig. 6 (left panel), which shows a zoom of the MODIS image for 1 April at 22:20 UTC in Fig. 3. There are yellow-brown, parallel, stripy features visible in the image. Blowing snow detection from MODIS is difficult as clouds and blowing snow particles both stand out in the mid-infrared (Palm et al., 2011) and therefore appear yellow in Fig. 6. It is therefore not clear if the stripy features are snow billows or just cloud streets, or a mixture of both. Nevertheless, as shown by WRF simulations (see above), the stripes occur in an area of high wind speeds and convergence, which most likely causes vertical lifting near the ground.
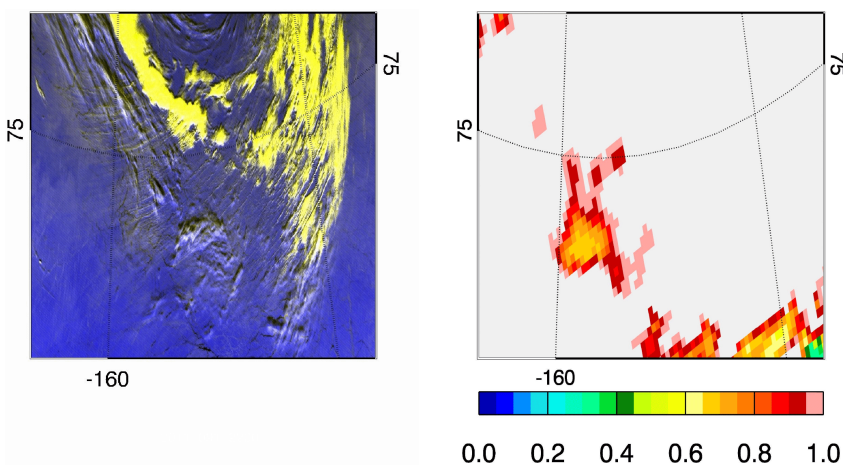

Figure 6. (Left) MODIS false colour image for 1 April 2011 at 22:20 UTC and (right) SMOS satellite retrievals of sea ice thickness [m] for 1 April 2011. Both panels show a subarea of the MODIS image given in the middle panel of Fig. 3e. In the MODIS image, snow and ice on the ground should appear blue, while clouds and suspended snow particles should appear yellow (see Sect.2.2).

Moreover, SMOS satellite observations (Fig. 6, right panel) show reduced sea ice thicknesses in the area of the stripy features observed by MODIS (see above). A reduced sea ice thickness indicates younger and saltier sea ice. Snow lying on top of younger sea ice, is covered in brine and more salty itself. This possibly favoured the bromine explosion chemical chain reaction together with weather conditions in the area of stripy features observed by MODIS.

Left panels in Fig. 7 show CALIOP vertical feature mask giving insight into vertical cloud and aerosol distributions inside the BrO plume for all development stages of the BCTE. CALIPSO footprints corresponding to these CALIOP observations are given by red and black dotted lines plotted on top of MODIS false colour images and GOME-2 tropospheric BrO VCDs in Fig. 3e and a, respectively. Again, further inspection of all MODIS observations of the BCTE available before and after each CALIOP observation indicates that MODIS observations shown in Fig. 3 are to a good approximation representative of cloud conditions at CALIOP observation times. Comparing the vertical feature masks with GOME-2 tropospheric BrO VCD along corresponding CALIPSO footprints (Fig. 7, right panels) shows that at the plume location, clouds and aerosols were restricted to about $3 \mathrm{~km}$ height in the vertical (with the exception of the onset of the event, for which some parts of the plume occurred in an area of higher cloud tops). Note that approximate $\mathrm{BrO}$ plume locations are indicated by red dashed boxes in Fig. 7. Cloud tops indicate boundaries regarding vertical mixing. Hence, it is likely that vertical transport of tropospheric bromine from the ground was also limited to $3 \mathrm{~km}$ height along CALIPSO footprints. However, the maximum time difference between CALIOP and GOME-2 observations is about $1.5 \mathrm{~h}$ so that cloud and aerosol conditions shown in Fig. 7 may differ in the vertical from the one at GOME-2 observation time. 
(a)
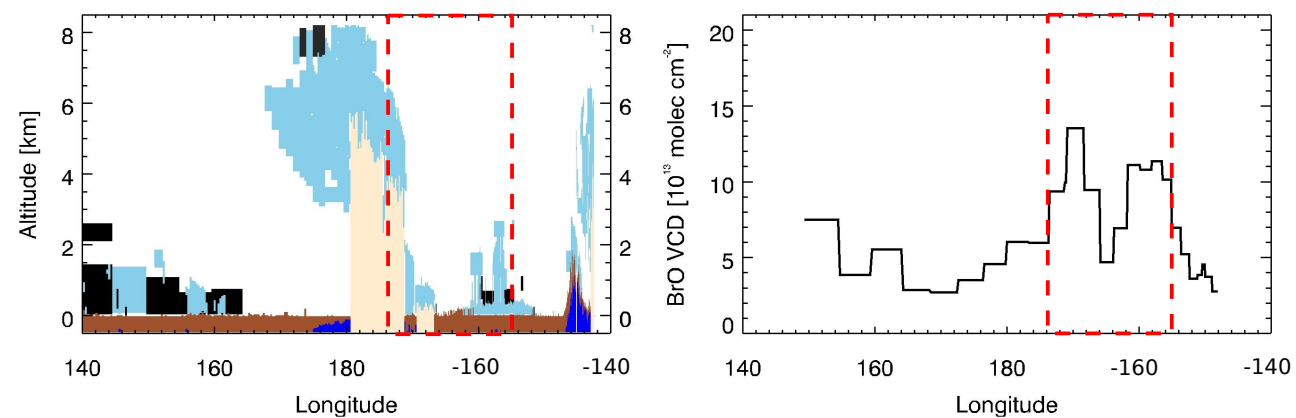

(b)
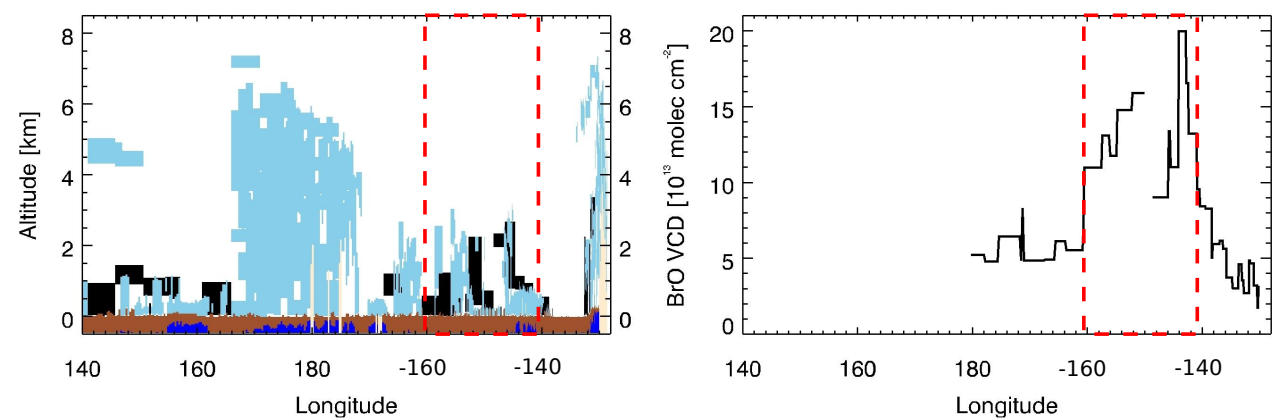

(c)
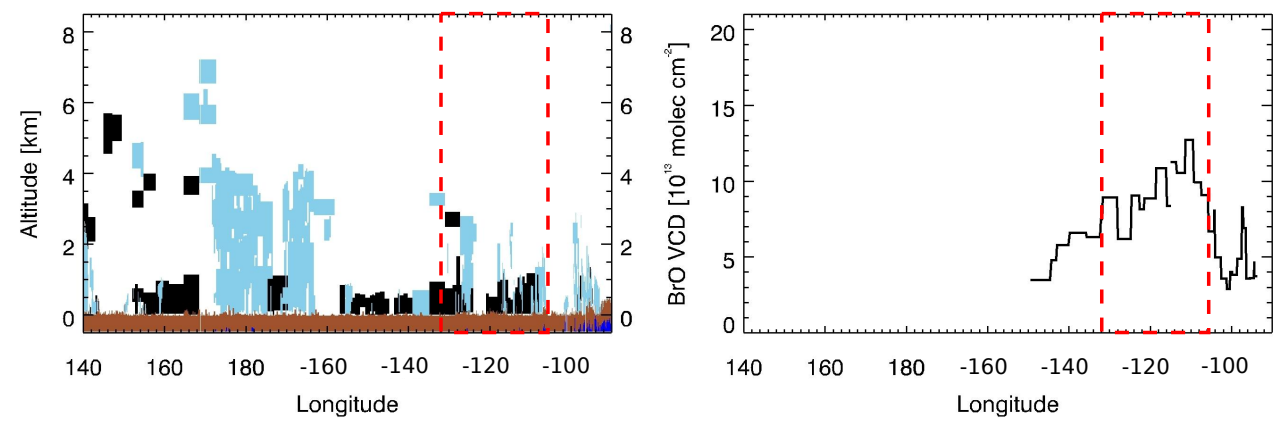

Figure 7. Satellite observations of the BCTE showing CALIOP vertical feature mask (white - clear air, light blue - cloud, black - aerosol, beige - no signal, brown - surface, dark blue - subsurface) on the left and GOME-2 BrO tropospheric VCD $\left[10^{13} \mathrm{molec}^{-2}\right] \mathrm{along}^{\mathrm{m}}$ CALIPSO tracks on the right. Corresponding CALIPSO tracks are plotted on top of GOME-2 BrO tropospheric VCD and MODIS false colour images in Fig. 3a and e, respectively. Shown are observations for different development stages of the BCTE: (a) onset (31 March 2011 at 21:17 UTC for CALIOP, 23:30 UTC for GOME-2), (b) mature stage (1 April 2011 at 20:21 UTC for CALIOP, 21:30 UTC for GOME-2) and (c) dissolving stage (2 April 2011 at 17:47 UTC for CALIOP, 19:30 UTC for GOME-2). The red dashed boxes indicate approximate locations of the $\mathrm{BrO}$ plume. Longitudes on $x$ axes are given in degrees East.

The WRF simulations indicate that the planetary boundary layer height (Fig. 4e) did not exceed $1 \mathrm{~km}$ in the vertical at plume location. This means that the $\mathrm{BrO}$ plume must have been transported out of the planetary boundary layer into the free troposphere, given that transport of $\mathrm{BrO}$ was most likely limited to $3 \mathrm{~km}$ height in the vertical.

FLEXPART simulations from FS1 for the mature and dissolving stage of the BCTE are displayed by Fig. 8 together with corresponding GOME-2 observations of tropospheric $\mathrm{BrO}$ VCD for reference. For 1 April, the best agreement between FLEXPART and GOME-2 is achieved by assuming that the $\mathrm{BrO}$ plume was located within a $1 \mathrm{~km}$ thick layer at the surface at time of initialisation (1 April at 00:00 UTC). The magnitude of $\mathrm{BrO}$ observations within the plume is reproduced well by FLEXPART. The model underestimates background values outside the $\mathrm{BrO}$ plume. The latter is most likely due to the fact that only satellite retrievals within a specific area around the $\mathrm{BrO}$ plume and above a $\mathrm{BrO}$ threshold value were used for model initialisation (see Sect. 3.2). This is also the case for all other FLEXPART results shown in this paper. The agreement between satellite retrievals and model output is also rather good regarding spatial distribution of the plume, for runs initialised by plumes between 1 and $7 \mathrm{~km}$ altitude (see Fig. 8c). Note that $1-3$ and 5-7 km plume results broadly resemble those for $3-5 \mathrm{~km}$ runs and are therefore not shown in Fig. 8. However, the magnitude of $\mathrm{BrO}$ tropospheric VCDs is considerably lower than those of the satellite observations and the plume slightly turns anticlockwise with height, so that the spatial agreement is not as good as for the surface plume run. Simulations substantially 
lose resemblance to GOME-2 retrievals for the 7-9 and 9$11 \mathrm{~km}$ runs (Fig. 8d and e, respectively), suggesting that a stratospheric origin of the $\mathrm{BrO}$ plume is rather unlikely.

In contrast to GOME-2 observations, FLEXPART still simulates a comma-shaped plume at the dissolving stage of the BCTE for the $0-1$ and $3-5 \mathrm{~km}$ simulations. Moreover, the plume is located northwards of where it actually occurred. The lowest elevation run overestimates satellite retrieved tropospheric VCDs of BrO. This may be due to the fact that no removal processes of $\mathrm{BrO}$ are included in the FLEXPART set-up. The higher elevation runs do not show a comma-shaped plume but again, the simulated plume is located further northwards of where it actually occurred. This is most likely due to the fact that emission sources are fixed to a specific point in time (1 April at 00:00 UTC for FS1) for FLEXPART simulations presented here. However, the shape of the $\mathrm{BrO}$ plume observed by GOME-2 most likely reflects the continuous change of emission sources associated with the passage of the front of the polar low pressure system.

FLEXPART simulations from FS2 and FS3 for the dissolving stage of the BCTE (together with the corresponding GOME-2 tropospheric BrO observation) are given in Fig. 9. Results for runs with emissions between 1 and $3 \mathrm{~km}$ and between 5 and $7 \mathrm{~km}$ look quite similar as results from the 3$5 \mathrm{~km}$ run and are therefore not shown in this figure. Like FS1, FS2 shows comma-shaped plumes for runs up to initialisation altitudes of 9-11 km. FS2 runs predict large values of tropospheric $\mathrm{BrO}$ vertical column density in the same area as the satellite observations, but also further northwards of the satellite observed plume. FS2 overestimates the magnitude of values reached inside the plume. In contrast to FS1 and FS2, FS3 results agree well with satellite observations at the dissolving stage of the BCTE. The simulated plume has largely lost its comma-shape for FS3. The best agreement between satellite retrievals and FS3 runs is achieved when assuming that the plume was located between 0 and $1 \mathrm{~km}$ altitude at time of initialisation (2 April 00:00 UTC). The fact that FS3 results compare much better with satellite data than FS2 and FS1 shows that emission sources around $150^{\circ} \mathrm{W}, 75^{\circ} \mathrm{N}$ contributed to the long observed lifetime (about 4 days) of the $\mathrm{BrO}$ plume. WRF simulations show that high wind speeds, convergent air flow and hence uplift occurred in this region (see above). This, together with SMOS and MODIS images suggests that recycling of bromine on salty blowing snow most likely caused the long observed lifetime of the BCTE. Note that as for FS1, differences between satellite retrieved tropospheric BrO VCDs and results from FS2 and FS3 are most likely due to the fact that the continuous change of emission sources associated with the passage of the front of the polar cyclone is not reflected by the FLEXPART simulations.

Overall, FLEXPART runs show that the plume was located in the troposphere with largest concentrations close to the surface, confirming that GOME-2 observed a tropospheric feature. Further investigation of FLEXPART runs shows that (a)
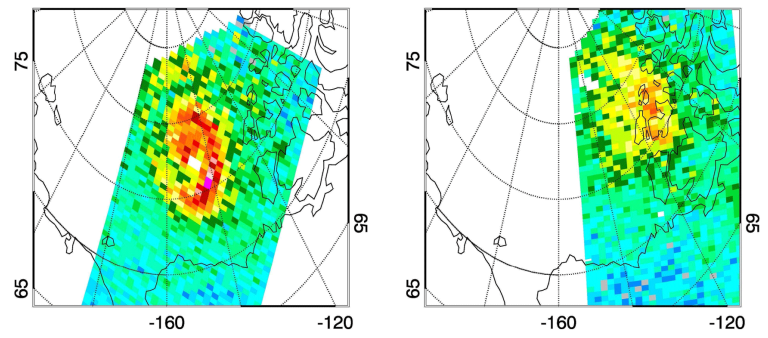

(b)
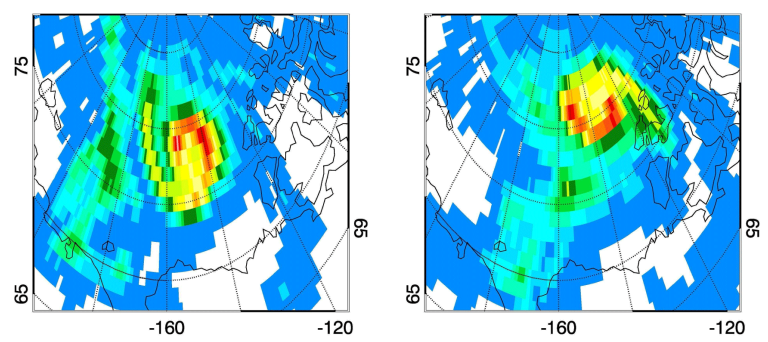

(c)
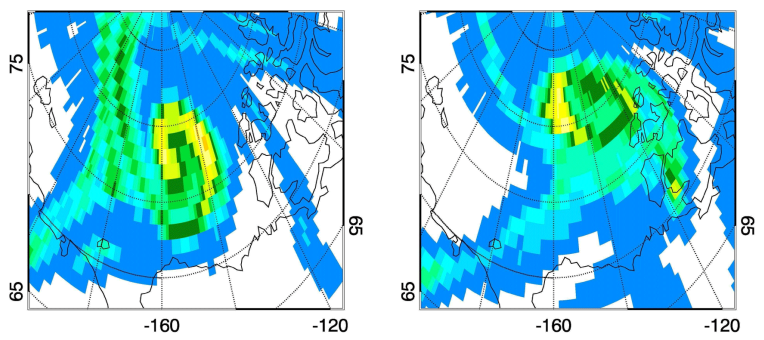

(d)
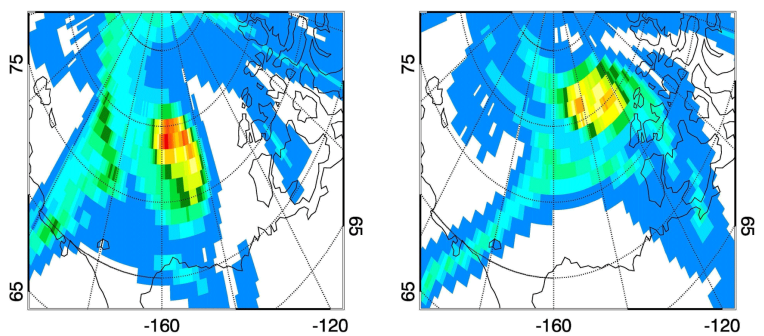

(e)
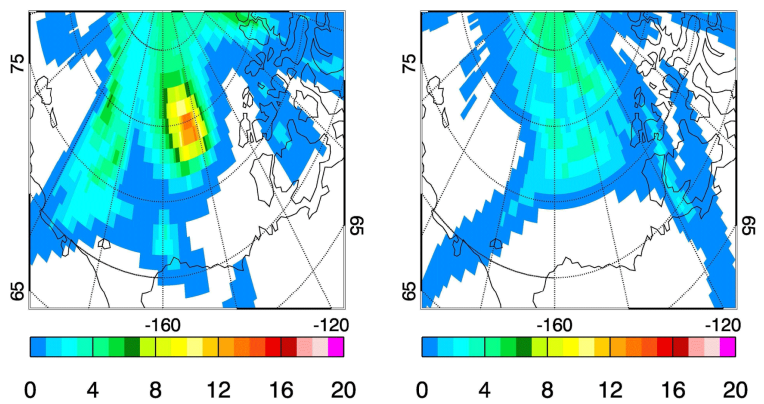

Figure 8. FLEXPART FS1 simulations of $\mathrm{BrO}$ tropospheric VCD $\left[10^{13} \mathrm{molec} \mathrm{cm}^{-2}\right]$ for (left) 1 April 2011 at 21:30 UTC (mature stage of the BCTE) and (right) 2 April 2011 at 19:30 UTC (dissolving stage of the BCTE) assuming that the plume was located between (b) $0-1 \mathrm{~km}$, (c) $3-5 \mathrm{~km}$, (d) $7-9 \mathrm{~km}$ and (e) $9-11 \mathrm{~km}$ altitude at time of initialisation. The corresponding GOME-2 retrievals of BrO tropospheric VCD $\left[10^{13}\right.$ molec $\left.\mathrm{cm}^{-2}\right]$ are shown by panels in (a) for comparison. See Sect. 3.2 for details on the model set-up. 
(a)

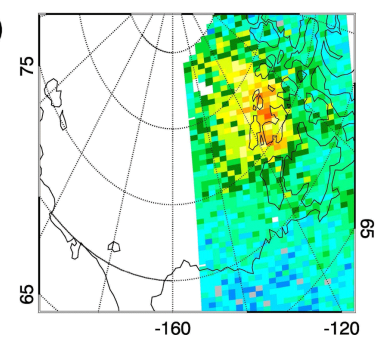

(b)

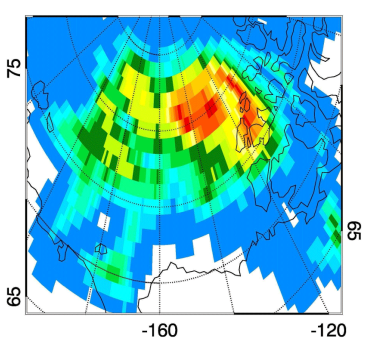

(c)

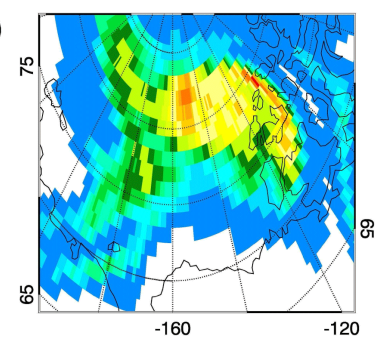

(d)

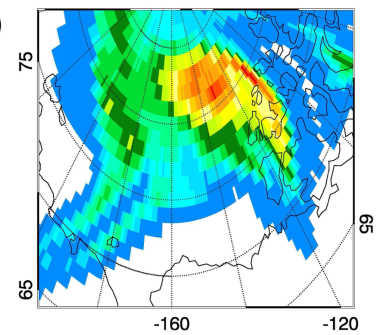

(e)

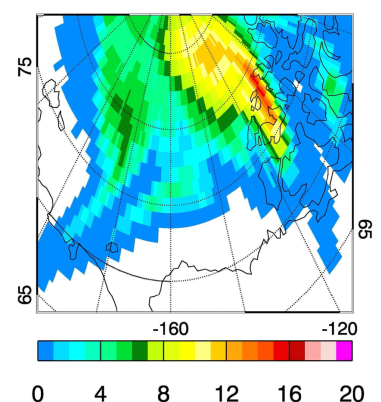

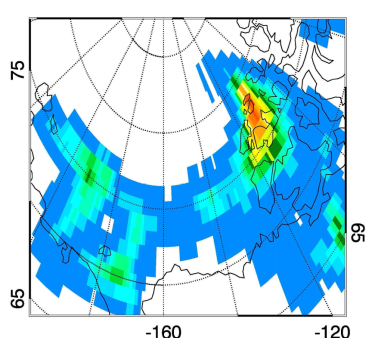
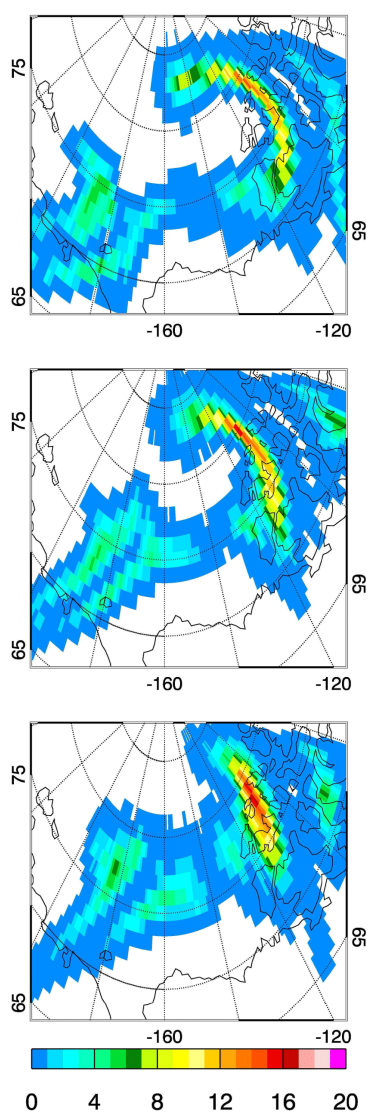

Figure 9. As in Fig. 8 but for FLEXPART (left) FS2 and (right) FS3 simulations for 2 April 2011 at 19:30 UTC (dissolving stage of the BCTE).

the plume resided between 0 and $3 \mathrm{~km}$ altitude during the whole simulation time. Provided that cloud top heights are representative of the upper limit of convection, FLEXPART simulations agree well with cloud top heights observed by CALIOP, further indicating that the $\mathrm{BrO}$ plume most likely occurred in the lowest three kilometres of the troposphere.

\section{Summary and conclusions}

An intense BCTE which developed on 31 March 2011 over the Beaufort Sea has been investigated based on a combined use of satellite observations and numerical models. Despite the short atmospheric lifetime of $\mathrm{BrO}$, the high wind speed BCTE was observed for about 4 days in GOME-2 satellite images. Comparison of GOME-2 satellite retrievals to FLEXPART and WRF model results reveals that the $\mathrm{BrO}$ plume moved eastwards with a polar low-pressure system. To our knowledge, this is the first study on a BEE that documents not only a link between plume occurrence and high boundary layer wind speeds, but also to frontal lifting near the cyclone centre as well as different development stages of the weather system. Our findings support Sihler et al. (2014) who stated that most of the ozone destruction during BEEs occurs in fronts. The BCTE intensified on 1 April in the evening, when the low pressure system deepened and wind speeds increased. The BCTE reached its dissolving stage on 2 April in the evening, when the low pressure system weakened and the cyclone lost frontal structure. High values of tropospheric BrO VCDs in regions of low wind speed which occurred near the cloud head at the onset and mature stage of the event can be explained by production of gas phase bromine in high wind speed regions and subsequent anticlockwise transport around the cyclone centre towards the cloud head.

The high wind speeds and vertical lifting associated with the front of the polar cyclone are consistent with weather conditions which cause production of blowing snow reported in other studies (e.g., Jones et al., 2009; Begoin et al., 2010). The MODIS false colour image from the mature stage of the BCTE shows mesoscale features resembling snow billows or cloud streets at the occluded front of the low in an area of high wind speeds and vertical uplift simulated by WRF. The latter coincides with reduced sea ice thicknesses retrieved from SMOS which means that any snow lying on sea ice in this area would have been more salty. Therefore, recycling of bromine on blowing snow is a reasonable explanation for the long observed lifetime of the plume and also for its development during the onset of the event. Moreover, the WRF simulations indicate that low temperatures in the area of the $\mathrm{BrO}$ plume in the lowest kilometre of the troposphere may have favoured the bromine activation cycle as proposed by Sander et al. (2006). Our results are consistent with Zhao et al. (2016) who observed the arrival of the $\mathrm{BrO}$ plume together with blowing snow at PEARL on 4 April with 
a MAX-DOAS instrument and Millimetre Cloud Radar data. Investigation of NCEP Reanalysis data (not shown) confirms that the BCTE initially developed when the low pressure system moved northwards towards the Beaufort Sea and reached potential source regions for salty blowing snow production observed by SMOS. Results presented in this paper document that weather conditions associated with fronts within polar cyclones are favourable not only for development of BEEs, but also to sustain high values of tropospheric $\mathrm{BrO}$ through continuous release of bromine over the course of the low pressure system, thereby extending plume lifetime substantially.

GOME-2 satellite observations of tropospheric $\mathrm{BrO}$ and total column ozone together with MODIS false colour images show that the plume was spatially separated from the dry conveyor belt associated with the polar cyclone. In this sense, this BEE differs from previous case studies for which the dry conveyor belt as a potentially bromine-rich stratospheric airstream complicated the interpretation of tropospheric $\mathrm{BrO}$ or total column $\mathrm{BrO}$ from satellite retrievals (e.g., Begoin et al., 2010; Salawitch et al., 2010). Moreover, FLEXPART simulations suggest that the BrO plume developed in a $1 \mathrm{~km}$ thick layer near the surface and was then transported up to $3 \mathrm{~km}$ altitude. This combination of model results and satellite observations shows that the $\mathrm{BrO}$ plume observed by GOME-2 most likely resided in the lowest parts of the troposphere over the entire lifetime of the BCTE. Our findings are consistent with Jones et al. (2010) who found that ozone depletion events which extend above $1 \mathrm{~km}$ in the vertical are usually associated with high wind speed conditions. Our results demonstrate that the close proximity of fronts and dry conveyor belts needs to be considered when deciding whether cyclone-like shaped plumes observed from satellite are of tropospheric or stratospheric origin, as both would be expected to show a comma- or spiral-shaped $\mathrm{BrO}$ pattern. This issue can be solved by using meteorological model data in combination with satellite observations.

The BrO plume occurred at the same location as low-level clouds observed by MODIS and CALIOP. As described in Sect. 2.1, light path enhancement and shielding of boundary layer BrO from the satellite sensors view cannot account for the plume pattern observed by GOME-2. Assuming that clouds are representative of vertical boundaries regarding convection, cloud and aerosol top heights observed by CALIOP agree well with FLEXPART results indicating that plume transport was limited to the lowest $3 \mathrm{~km}$ of the atmosphere.

In recent years, global climate models have been extended to successfully reproduce tropospheric $\mathrm{BrO}$ and BEEs observed by satellite (e.g., Yang et al., 2010). However, our results suggest that a mesoscale model like WRF/Chem (Grell et al., 2005) may be better suited for incorporating the bromine explosion chemical mechanism in a chemical transport model, as mesoscale snow billows produced by high wind speeds will not be resolved by global models.
As the present paper is based on one event only, more studies characterising links between polar cyclones and BCTEs on a climatological basis are required. Especially links to fronts should be investigated further. Moreover, possible links between strength and frequency of BCTEs and climate change need to be investigated in future research. Our results suggest that global warming potentially not only affects strength and frequency of BEEs by replacing perennial by younger sea ice (Nghiem et al., 2012), but also through effects on cyclone strength and frequency. According to Vavrus (2013), the frequency of extreme Arctic cyclones is expected to increase as a result of global warming. This, in addition to an increased area of younger sea ice, may lead to more frequent BCTEs in the future. This in turn impacts on the oxidative capacity of high-latitudes, the depletion of tropospheric $\mathrm{O}_{3}$ and deposition of mercury.

In summary, this manuscript has demonstrated the important role of frontal systems in generating tropospheric $\mathrm{BrO}$ in the lower troposphere. Further studies are required to quantify the relative importance of surface production of $\mathrm{BrO}$ and brine coated snow and ice lifted by frontal systems, future changes of BCTEs as well as their impact on tropospheric chemistry.

Acknowledgements. This study was funded in part by the University of Bremen. Thanks to Larisa Istomina and Maximilian Reuter from IUP-Bremen for their help with the interpretation of MODIS satellite images. We thank Holger Sihler from IUPHeidelberg for helpful discussions on $\mathrm{BrO}$ transport. Thanks to people behind the CISL Research Data Archive for providing NCEP data on their web site. CALIPSO data were provided by the NASA Langley Research Center Atmospheric Science Data Center (http://eosweb.larc.nasa.gov/). MODIS data were obtained from http://modis.gsfc.nasa.gov/. We thank the developers of WRF and FLEXPART for providing model source code on their webpages (http://www2.mmm.ucar.edu/wrf/users/ and https://flexpart.eu/, respectively). We thank the two anonymous referees of this manuscript for their effort and very helpful comments and suggestions.

The article processing charges for this open-access publication were covered by the University of Bremen.

Edited by: M. Van Roozendael 


\section{References}

Afe, O. T., Richter, A., Sierk, B., Wittrock, F., and Burrows, J. P.: BrO emission from volcanoes: A survey using GOME and SCIAMACHY measurements, Geophys. Res. Lett., 31, L24113, doi:10.1029/2004GL020994, 2004.

Barrie, L. A., Bottenheim, J. W., Schnell, R. C., Crutzen, P. J., and Rasmussen, R. A.: Ozone destruction and photochemical reactions at polar sunrise in the lower Arctic atmosphere, Nature, 334, 138-141, 1988.

Barrie, L. and Platt, U.: Arctic tropospheric chemistry: an overview, Tellus B, 49, 450-454, 1997.

Begoin, M., Richter, A., Weber, M., Kaleschke, L., Tian-Kunze, X., Stohl, A., Theys, N., and Burrows, J. P.: Satellite observations of long range transport of a large BrO plume in the Arctic, Atmos. Chem. Phys., 10, 6515-6526, doi:10.5194/acp-10-65152010, 2010.

Bottenheim, J. W., Netcheva, S., Morin, S., and Nghiem, S. V.: Ozone in the boundary layer air over the Arctic Ocean: measurements during the TARA transpolar drift 2006-2008, Atmos. Chem. Phys., 9, 4545-4557, doi:10.5194/acp-9-4545-2009, 2009.

Bracher, A., Lamsal, L. N., Weber, M., Bramstedt, K., ColdeweyEgbers, M., and Burrows, J. P.: Global satellite validation of SCIAMACHY $\mathrm{O}_{3}$ columns with GOME WFDOAS, Atmos. Chem. Phys., 5, 2357-2368, doi:10.5194/acp-5-2357-2005, 2005.

Browning, K. A.: The dry intrusion perspective of extra-tropical cyclone development, Meteorol. Appl., 4, 317-324, 1997.

Burrows, J. P., Dehn, A., Deters, B., Himmelmann, S., Richter, A., Voigt, S., and Orphal, J.: Atmospheric remote-sensing reference data from GOME - Part 1: Temperature-dependent absorption cross-sections of $\mathrm{NO}_{2}$ in the 231-794 nm range, J. Quant. Spectrosc. Ra., 60, 1025-1031, 1998.

Buys, Z., Brough, N., Huey, L. G., Tanner, D. J., von Glasow, R., and Jones, A. E.: High temporal resolution $\mathrm{Br}_{2}, \mathrm{BrCl}$ and BrO observations in coastal Antarctica, Atmos. Chem. Phys., 13, 1329-1343, doi:10.5194/acp-13-1329-2013, 2013.

Callies, J., Corpaccioli, E., Eisinger, M., Hahne, A., and Lefebvre, A.: GOME-2 - Metop's second-generation sensor for operational ozone monitoring, ESA Bulletin, 102, 28-36, 2000.

Choi, S., Wang, Y., Salawitch, R. J., Canty, T., Joiner, J., Zeng, T., Kurosu, T. P., Chance, K., Richter, A., Huey, L. G., Liao, J., Neuman, J. A., Nowak, J. B., Dibb, J. E., Weinheimer, A. J., Diskin, G., Ryerson, T. B., da Silva, A., Curry, J., Kinnison, D., Tilmes, S., and Levelt, P. F.: Analysis of satellite-derived Arctic tropospheric $\mathrm{BrO}$ columns in conjunction with aircraft measurements during ARCTAS and ARCPAC, Atmos. Chem. Phys., 12, 12551285, doi:10.5194/acp-12-1255-2012, 2012.

Coldewey-Egbers, M., Weber, M., Lamsal, L. N., de Beek, R., Buchwitz, M., and Burrows, J. P.: Total ozone retrieval from GOME UV spectral data using the weighting function DOAS approach, Atmos. Chem. Phys., 5, 1015-1025, doi:10.5194/acp5-1015-2005, 2005.

Domine, F., Taillandier, A. S., Simpson, W. R., and Severin, K.: Specific surface area, density and microstructure of frost flowers, Geophys. Res. Lett., 32, L13502, doi:10.1029/2005GL023245, 2005 .
Dudhia, J.: Numerical study of convection observed during the Winter Monsoon Experiment using a mesoscale two-dimensional model, J. Atmos. Sci., 46, 3077-3107, 1989.

Errera, Q., Daerden, F., Chabrillat, S., Lambert, J. C., Lahoz, W. A., Viscardy, S., Bonjean, S., and Fonteyn, D.: 4D-Var assimilation of MIPAS chemical observations: ozone and nitrogen dioxide analyses, Atmos. Chem. Phys., 8, 6169-6187, doi:10.5194/acp8-6169-2008, 2008.

Fickert, S., Adams, J. W., and Crowley, J. N.: Activation of $\mathrm{Br}_{2}$ and $\mathrm{BrCl}$ via uptake of $\mathrm{HOBr}$ onto aqueous salt solutions, J. Geophys. Res., 104, 23719-23727, doi:10.1029/1999JD900359, 1999.

Fleischmann, O. C., Hartmann, M., Burrows, J. P., and Orphal, J.: New ultraviolet absorption cross-sections of $\mathrm{BrO}$ at atmospheric temperatures measured by time-windowing Fourier transform spectroscopy, J. Photochem. Photobiol. A: Chemistry, 168, 117132, doi:10.1016/j.jphotochem.2004.03.026, 2004.

Frieß, U., Hollwedel, J., Konig-Langlo, G., Wagner, T., and Platt, U.: Dynamics and chemistry of tropospheric bromine explosion events in the Antarctic coastal region, J. Geophys. Res., 109, D06305, doi:10.1029/2003JD004133, 2004.

Frieß, U., Sihler, H., Sander, R., Pöhler, D., Yilmaz, S., and Platt, U.: The vertical distribution of $\mathrm{BrO}$ and aerosols in the Arctic: measurements by active and passive differential optical absorption spectroscopy, J. Geophys. Res., 116, D00R04, doi:10.1029/2011JD015938, 2011.

Gilman, J. B., Burkhart, J. F., Lerner, B. M., Williams, E. J., Kuster, W. C., Goldan, P. D., Murphy, P. C., Warneke, C., Fowler, C., Montzka, S. A., Miller, B. R., Miller, L., Oltmans, S. J., Ryerson, T. B., Cooper, O. R., Stohl, A., and de Gouw, J. A.: Ozone variability and halogen oxidation within the Arctic and sub-Arctic springtime boundary layer, Atmos. Chem. Phys., 10, 10223-10236, doi:10.5194/acp-10-10223-2010, 2010.

Gorshelev, V., Serdyuchenko, A., Weber, M., Chehade, W., and Burrows, J. P.: High spectral resolution ozone absorption crosssections - Part 1: Measurements, data analysis and comparison with previous measurements around 293 K, Atmos. Meas. Tech., 7, 609-624, doi:10.5194/amt-7-609-2014, 2014.

Grell, G. A., Peckham, S. E., Schmitz, R., McKeen, S. A., Frost, G., Skamarock, W. C., and Eder, B.: Fully coupled online chemistry within the WRF model, Atmos. Environ., 39, 6957-6976, doi:10.1016/j.atmosenv.2005.04.027, 2005.

Hirdman, D., Burkhart, J. F., Sodemann, H., Eckhardt, S., Jefferson, A., Quinn, P. K., Sharma, S., Ström, J., and Stohl, A.: Longterm trends of black carbon and sulphate aerosol in the Arctic: changes in atmospheric transport and source region emissions, Atmos. Chem. Phys., 10, 9351-9368, doi:10.5194/acp-10-93512010, 2010.

Hollwedel, J., Wenig, M., Beirle, S., Kraus, S., Kühl, S., WilmsGrabe, W., Platt, U., and Wagner, T.: Year-to-Year Variations of Polar Tropospheric BrO as seen by GOME, Adv. Space Res., 34, 804-808, doi:10.1016/j.asr.2003.08.060, 2004.

Jacobi, H.-W., Morin, S., and Bottenheim, J. W.: Observation of widespread depletion of ozone in the springtime boundary layer of the central Arctic linked to mesoscale synoptic conditions, J. Geophys. Res., 115, D17302, doi:10.1029/2010JD013940, 2010.

Janjic, Z. I.: The Step-Mountain Eta Coordinate Model: Further developments of the convection, viscous sublayer, and turbulence closure schemes, Mon. Weather Rev., 122, 927-945, 1994. 
Jones, A. E., Anderson, P. S., Begoin, M., Brough, N., Hutterli, M. A., Marshall, G. J., Richter, A., Roscoe, H. K., and Wolff, E. W.: $\mathrm{BrO}$, blizzards, and drivers of polar tropospheric ozone depletion events, Atmos. Chem. Phys., 9, 4639-4652, doi:10.5194/acp-94639-2009, 2009.

Jones, A. E., Anderson, P. S., Wolff, E. W., Roscoe, H. K., Marshall, G. J., Richter, A., Brough, N., and Colwell, S. R.: Vertical structure of Antarctic tropospheric ozone depletion events: characteristics and broader implications, Atmos. Chem. Phys., 10, 7775-7794, doi:10.5194/acp-10-7775-2010, 2010.

Jones, A. E., Wolff, E. W., Brough, N., Bauguitte, S. J.-B., Weller, R., Yela, M., Navarro-Comas, M., Ochoa, H. A., and Theys, N.: The spatial scale of ozone depletion events derived from an autonomous surface ozone network in coastal Antarctica, Atmos. Chem. Phys., 13, 1457-1467, doi:10.5194/acp-13-1457-2013, 2013.

Kaleschke, L., Richter, A., Burrows, J. P., Afe, O., Heygster, G., Notholt, J., Rankin, A. M., Roscoe, H. K., Hollwedel, J., Wagner, T., and Jacobi, H.-W.: Frost flowers on sea ice as a source of sea salt and their influence on tropospheric halogen chemistry, Geophys. Res. Lett., 31, L16114, doi:10.1029/2004GL020655, 2004.

Kaleschke, L., Tian-Kunze, X., Maaß, N., Mäkynen, M., and Drusch, M.: Sea ice thickness retrieval from SMOS brightness temperatures during the Arctic freeze-up period, Geophys. Res. Lett., 39, L05501, doi:10.1029/2012GL050916, 2012.

Kalnay, E., Kanamitsu, M., Kistler, R., Collins, W., Deaven, D., Gandin, L., Iredell, M., Saha, S., White, G., Woollen, J., Zhu, Y., Leetmaa, A., Reynolds, R., Chelliah, M., Ebisuzaki, W., Higgins, W., Janowiak, J., Mo, K. C., Ropelewski, C., Wang, J., Jenne, R., and Joseph, D.: The NCEP/NCAR 40-Year Reanalysis Project, B. Am. Meteorol. Soc., 77, 437-471, doi:10.1175/15200477(1996)077<0437:tnyrp>2.0.CO;2, 1996.

Koo, J.-H., Wang, Y., Kurosu, T. P., Chance, K., Rozanov, A., Richter, A., Oltmans, S. J., Thompson, A. M., Hair, J. W., Fenn, M. A., Weinheimer, A. J., Ryerson, T. B., Solberg, S., Huey, L. G., Liao, J., Dibb, J. E., Neuman, J. A., Nowak, J. B., Pierce, R. B., Natarajan, M., and Al-Saadi, J.: Characteristics of tropospheric ozone depletion events in the Arctic spring: analysis of the ARCTAS, ARCPAC, and ARCIONS measurements and satellite BrO observations, Atmos. Chem. Phys., 12, 9909-9922, doi:10.5194/acp-12-9909-2012, 2012.

Lehrer, E., Wagenbach, D., and Platt, U.: Aerosol chemical composition during tropospheric ozone depletion at Ny Alesund/Svalbard, Tellus B, 49, 486-495, 1997.

Lin, Y.-L., Farley, R. D., and Orville, H. D.: Bulk parameterization of the snow field in a cloud model, J. Climate Appl. Meteor., 22, 1065-1092, 1983.

Mlawer, E. J., Taubman, S. J., Brown, P. D., Iacono, M. J., and Clough, S. A.: Radiative transfer for inhomogeneous atmospheres: RRTM, a validated correlated-k model for the longwave, J. Geophys. Res., 102, 16663-16682, 1997.

Nghiem, S. V., Rigor, I. G., Richter, A., Burrows, J. P., Shepson, P. B., Bottenheim, J., Barber, D. G., Steffen, A., Latonas, J. , Wang, J., Stern, G., Clemente-Coln, P., Martin, S., Hall, D. K., Kaleschke, L., Tackett, P., Neumann, G., Asplin, M. G.: Field and satellite observations of the formation and distribution of Arctic atmospheric bromine above a rejuvenated sea ice cover, J. Geophys. Res., 117, D00S05, doi:10.1029/2011JD016268, 2012.
Obbard, R. W., Roscoe, H. K., Wolff, E. W., and Atkinson, H. M.: Frost flower surface area and chemistry as a function of salinity and temperature, J. Geophys. Res., 114, D20305, doi:10.1029/2009JD012481, 2009.

Palm, S. P., Yang, Y., Spinhirne, J. D., and Marshak, A.: Satellite remote sensing of blowing snow properties over Antarctica, J. Geophys. Res., 116, D16123, doi:10.1029/2011JD015828, 2011.

Platt, U.: Differential optical absorption spectroscopy (DOAS), in: Air Monitoring by Spectroscopic Techniques, edited by: Sigrist, M. W., John Wiley, New York, 27-84, 1994.

Platt, U. and Lehrer, E.: Arctic Tropospheric Ozone Chemistry, ARCTOC, Final Report of the EU-Project No. EV5V-CT930318, 1997.

Pratt, K. A., Kyle, D. C., Shepson, P. B., Douglas, T. A., Pöhler, D., General, S., Zielcke, J., Simpson, W. R., Platt, U., Tanner, D. J., Huey, L. G., Carlsen, M., and Stirm, B. H.: Photochemical production of molecular bromine in Arctic surface snowpacks, Nat. Geosci., 6, 351-356, doi:10.1038/ngeo1779, 2013.

Rankin, A. M., Wolff, E. W., and Martin, S.: Frost flowers - implications for tropospheric chemistry and ice core interpretation, J Geophys. Res., 107, 4683, doi:10.1029/2002JD002492, 2002.

Richter, A., Wittrock, F., Eisinger, M., and Burrows, J. P.: GOME observations of tropospheric $\mathrm{BrO}$ in Northern Hemispheric spring and summer 1997, Geophys. Res. Lett., 25, 2683-2686, doi:10.1029/98GL52016, 1998.

Roscoe, H. K., Brooks, B., Jackson, A. V., Smith, M. H., Walker, S. J., Obbard, R. W., and Wolff, E. W.: Frost flowers in the laboratory: Growth, characteristics, aerosol, and the underlying sea ice, J. Geophys. Res., 116, D12301, doi:10.1029/2010JD015144, 2011.

Rozanov, A., Rozanov, V., Buchwitz, M., Kokhanovsky, A., and Burrows, J. P.: SCIATRAN 2.0 - A new radiative transfer model for geophysical applications in the $175-2400 \mathrm{~nm}$ spectral region, Adv. Space Res., 36, 1015-1019, doi:10.1016/j.asr.2005.03.012, 2005.

Salawitch, R. J., Canty, T., Kurosu, T., Chance, K., Liang, Q., da Silva, A., Pawson, S., Nielsen, J. E., Rodriguez, J. M., Bhartia, P. K., Liu, X., Huey, L. G., Liao, J., Stickel, R. E., Tanner, D. J., Dibb, J. E., Simpson, W. R., Donohoue, D., Weinheimer, A. J., Flocke, F., Knapp, D., Montzka, D. D., Neuman, J. A., Nowak, J. B., Ryerson, T. B., Oltmans, S., Blake, D. R., Atlas, E. L., Kinnison, D. E., Tilmes, S., Pan, L. L., Hendrick, F., Van Roozendael, M., Kreher, K., Johnston, P. V., Gao, R. S., Johnson, B., Bui, T. P., Chen, G., Pierce, R. B., Crawford, J. H., and Jacob, D. J.: A New interpretation of total column BrO during Arctic spring, Geophys. Res. Lett., 37, L21805, doi:10.1029/2010GL043798, 2010.

Sander, R., Burrows, J., and Kaleschke, L.: Carbonate precipitation in brine - a potential trigger for tropospheric ozone depletion events, Atmos. Chem. Phys., 6, 4653-4658, doi:10.5194/acp-64653-2006, 2006.

Serdyuchenko, A., Gorshelev, V., Weber, M., Chehade, W., and Burrows, J. P.: High spectral resolution ozone absorption crosssections -Part 2: Temperature dependence, Atmos. Meas. Tech., 7, 625-636, doi:10.5194/amt-7-625-2014, 2014.

Sihler, H., Platt, U., Beirle, S., Marbach, T., Kühl, S., Dörner, S., Verschaeve, J., Frieß, U., Pöhler, D., Vogel, L., Sander, R., and Wagner, T.: Tropospheric BrO column densities in the Arctic derived from satellite: retrieval and comparison to 
ground-based measurements, Atmos. Meas. Tech., 5, 27792807, doi:10.5194/amt-5-2779-2012, 2012.

Sihler, H., Dörner, S., Pozzer, A., Frieß, U., Platt, U., and Wagner, T.: Meteorology and vertical structure of plumes of enhanced bromine monoxide as detected by satellite remote sensing during Arctic spring, EGU General Assembly, Vienna, Austria, 27 April-2 May 2014, EGU2014-15426, 2014.

Simpson, W. R., Carlson, D., Hönninger, G., Douglas, T. A., Sturm, M., Perovich, D., and Platt, U.: First-year sea-ice contact predicts bromine monoxide $(\mathrm{BrO})$ levels at Barrow, Alaska better than potential frost flower contact, Atmos. Chem. Phys., 7, 621-627, doi:10.5194/acp-7-621-2007, 2007.

Simpson, W. R., von Glasow, R., Riedel, K., Anderson, P., Ariya, P., Bottenheim, J., Burrows, J., Carpenter, L. J., Frieß, U., Goodsite, M. E., Heard, D., Hutterli, M., Jacobi, H.-W., Kaleschke, L., Neff, B., Plane, J., Platt, U., Richter, A., Roscoe, H., Sander, R., Shepson, P., Sodeau, J., Steffen, A., Wagner, T., and Wolff, E.: Halogens and their role in polar boundary-layer ozone depletion, Atmos. Chem. Phys., 7, 4375-4418, doi:10.5194/acp-74375-2007, 2007.

Skamarock, W. C., Klemp, J. B., Dudhia, J., Gill, D. O., Barker, D. M., Duda, M., Huang, X.-Y., Wang, W., and Powers, J. G.: A Description of the Advanced Research WRF Version 3, NCAR Technical note NCAR/TN-475+STR, doi:10.5065/D68S4MVH, NCAR, Boulder (Colorado), 2008.

Steffen, A., Douglas, T., Amyot, M., Ariya, P., Aspmo, K., Berg, T., Bottenheim, J., Brooks, S., Cobbett, F., Dastoor, A., Dommergue, A., Ebinghaus, R., Ferrari, C., Gardfeldt, K., Goodsite, M. E., Lean, D., Poulain, A. J., Scherz, C., Skov, H., Sommar, J., and Temme, C.: A synthesis of atmospheric mercury depletion event chemistry in the atmosphere and snow, Atmos. Chem. Phys., 8, 1445-1482, doi:10.5194/acp-8-1445-2008, 2008.

Stohl, A.: Characteristics of atmospheric transport into the Arctic troposphere, J. Geophys. Res., 111, D11306, doi:10.1029/2005JD006888, 2006.

Stohl, A., Forster, C., Frank, A., Seibert, P., and Wotawa, G.: Technical note: The Lagrangian particle dispersion model FLEXPART version 6.2, Atmos. Chem. Phys., 5, 2461-2474, doi:10.5194/acp-5-2461-2005, 2005.

Tarasick, D. W. and Bottenheim, J. W.: Surface ozone depletion episodes in the Arctic and Antarctic from historical ozonesonde records, Atmos. Chem. Phys., 2, 197-205, doi:10.5194/acp-2197-2002, 2002.

Theys, N., Van Roozendael, M., Hendrick, F., Yang, X., De Smedt, I., Richter, A., Begoin, M., Errera, Q., Johnston, P. V., Kreher, K., and De Mazière, M.: Global observations of tropospheric $\mathrm{BrO}$ columns using GOME-2 satellite data, Atmos. Chem. Phys., 11, 1791-1811, doi:10.5194/acp-11-1791-2011, 2011.

Tian-Kunze, X., Kaleschke, L., Maßß, N., Mäkynen, M., Serra, N., Drusch, M., and Krumpen, T.: SMOS-derived thin sea ice thickness: algorithm baseline, product specifications and initial verification, The Cryosphere, 8, 997-1018, doi:10.5194/tc-8-9972014, 2014.
Vasilkov, A. P., Joiner, J., Haffner, D., Bhartia, P. K., and Spurr, R. J. D.: What do satellite backscatter ultraviolet and visible spectrometers see over snow and ice? A study of clouds and ozone using the A-train, Atmos. Meas. Tech., 3, 619-629, doi:10.5194/amt3-619-2010, 2010.

Vavrus, S. J.: Extreme Arctic cyclones in CMIP5 historical simulations, Geophys. Res. Lett., 40, 6208-6212, doi:10.1002/2013GL058161, 2013.

Viscardy, S., Errera, Q., Christophe, Y., Chabrillat, S., and Lambert, J.-C.: Evaluation of ozone analysis from UARS MLS assimilation by BASCOE between 1992 and 1997, JSTARS, 3, 190-202, 2010.

Vogt, R., Crutzen, P. J., and Sander, R.: A mechanism for halogen release from sea-salt aerosol in the remote marine boundary layer, Nature, 383, 327-330, doi:10.1038/383327A0, 1996.

Vountas, M., Rozanov, V.V. and Burrows, J.P.: Ring-effect: Impact of rotational raman scattering on radiative transfer in earth's atmosphere, J. Quant. Spectrosc. Radiat. Transfer, 60, 943-961, doi:10.1016/S0022-4073(97)00186-6, 1998.

Wagner, T. and Platt, U.: Satellite mapping of enhanced BrO concentrations in the troposphere, Nature, 395, 486-490, 1998.

Wagner, T., Leue, C., Wenig, M., Pfeilsticker, K., and Platt, U.: Spatial and temporal distribution of enhanced boundary layer $\mathrm{BrO}$ concentrations measured by the GOME instrument aboard ERS-2, J. Geophys. Res., 106, 24225-24235, doi:10.1029/2000JD000201, 2001.

Warneke, C., Bahreini, R., Brioude, J., Brock, C. A., de Gouw, J. A., Fahey, D. W., Froyd, K. D., Holloway, J. S., Middlebrook, A., Miller, L., Montzka, S., Murphy, D. M., Peischl, J., Ryerson, T. B., Schwarz, J. P., Spackman, J. R., and Veres, P.: Biomass burning in Siberia and Kazakhstan as an important source for haze over the Alaskan Arctic in April 2008, Geophys. Res. Lett., 36, L02813, doi:10.1029/2008GL036194, 2009.

Weber, M., Lamsal, L. N., Coldewey-Egbers, M., Bramstedt, K., and Burrows, J. P.: Pole-to-pole validation of GOME WFDOAS total ozone with groundbased data, Atmos. Chem. Phys., 5, 1341-1355, doi:10.5194/acp-5-1341-2005, 2005.

Yang, X., Pyle, J. A., Cox, R. A., Theys, N., and Van Roozendael, M.: Snow-sourced bromine and its implications for polar tropospheric ozone, Atmos. Chem. Phys., 10, 7763-7773, doi:10.5194/acp-10-7763-2010, 2010.

Zhao, X., Strong, K., Adams, C., Schofield, R., Yang, X., Richter, A., Frieß, U., Blechschmidt, A.-M., and Koo, J.-H.: A case study of a transported bromine explosion event in the Canadian high Arctic, J. Geophys. Res. Atmos., 121, 457-477, doi:10.1002/2015JD023711, 2016. 